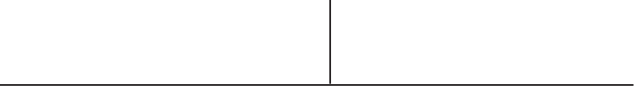

Rev. Latinoam. Psicopat. Fund., São Paulo, 16(4),642-682, dez. 2013

\title{
CONSIDERACOES GERAS
}

\author{
SOBRE
}

a atienagad mentad.

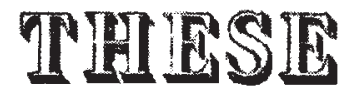

APRESENTADA E SUSTENTADA

A 29 DE NOVEMBRO DE 1857

PERANTF

\section{A FACULDADE DE MEDICINA}

\section{DO RIO DE JAKETHO,}

$$
\text { POR }
$$

Antonio Luiz da Silva Peixoto,

NATUMAL DO RO DE JANIRO.

DOVTOH EM MEDICINA, E CIAVIGLA APPROVADO PLLA MESALA FACULDADE.

Da reniam seriptis, quorum nan gloria nobis

Cacsa, sed ulilitas, offrinanque ruil.

or. LB Fukro, tis. $\mathrm{s}_{\text {, }}$

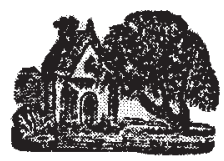

\section{RIO DE JANEIRO,}

NA TYPOGRAPHIA E LIVR SRIA DE L. A. BURGAIN,

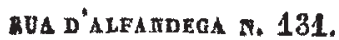




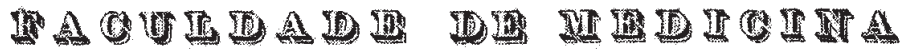

\section{DO RIO DE JA N E RO.}

\author{
OS SNRS. DOUTORES
}

\section{IMNTHS PROPRImARTOS.}

Conselheiro D. R. Dos G. PEIXoTo . . . . . . Divector.

Annos.

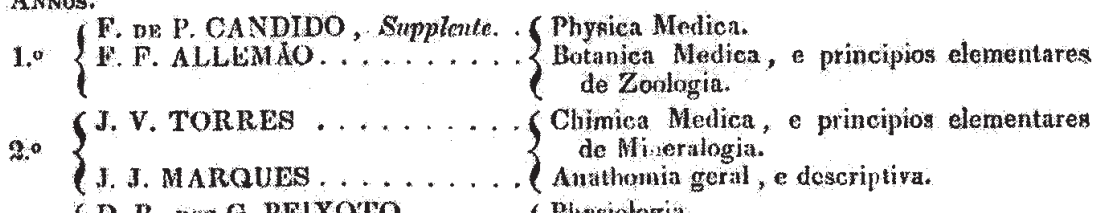

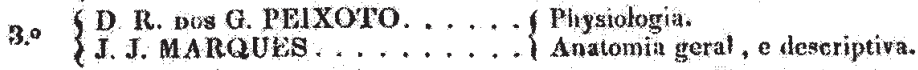

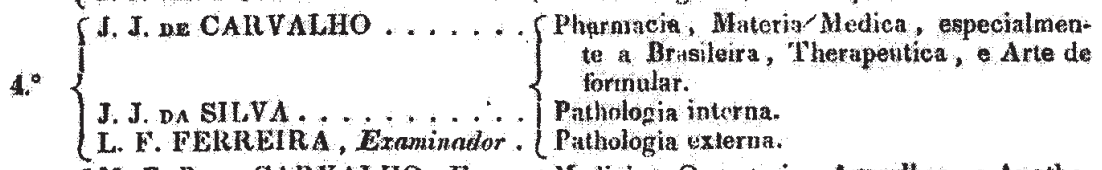

5.o $\left\{\begin{array}{l}\text { M. F. P. de CARVALHO, Exan. } \\ \text { F. J. Xavier, Examinador..... }\end{array}\right.$

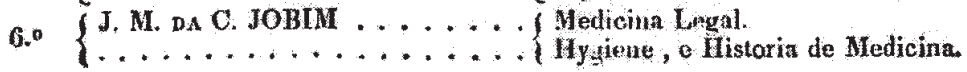

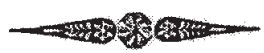

M. no V॰PIMENTEL, Presidente. $\left\{\begin{array}{c}\text { Cinica interna, annexa aos } 5.0,60.0 \\ \text { annos. }\end{array}\right.$

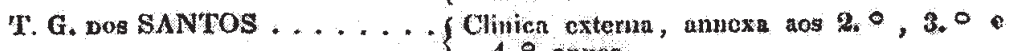
4.0 anuos.

Rev. Latinoam. Psicopat. Fund., Bãentutes 1 St)

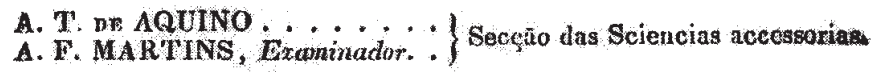

J. B. Da ROZA, Sopplente, ...
L. DE A. P. DA CUNHA, Exam. Secto Medica.

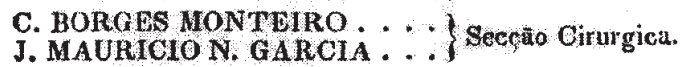

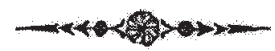

L. C. da FoNseCA ............. Secretario.

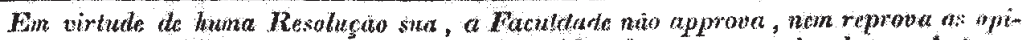
nioes emittidas nus Theses, as quaes dcoom ser consideralas como proprias de seus Autores. 


\section{Considerações gerais sobre a alienação mental (1837)*}

Antonio Luiz da Silva Peixoto

\section{$\grave{A}$}

Muito amante e extremosa mãe,

Ilma. Sra. D. Anna Bernarda de Alvarenga Peixoto.

Minha boa mãe e senhora. - Aos incansáveis cuidados e desvelos, que de mim tivestes desde a minha infância, não vos poupando a sacrifícios, ainda os mais pesados, para dardes a mim (e a todos os vossos filhos) uma educação que fosse consentânea com os vossos bons princípios e costumes, é que eu devo a glória que hoje me cabe, vendo com um nobre orgulho terminada a carreira escolástica que encetara. Eis o fruto da vossa obra!

Se é justo que a primeira colheita pertença à benfazeja mão que lançara a semente sobre a terra, a quem mais que a vós dedicaria eu o primeiro ensaio do meu tirocínio médico? Eu, pois, o ofereço a vós, e possa a invencível égide com que vai acoberto defendê-lo dos erros que os críticos, decerto, lhe enxergarão.

Aceite, portanto, minha boa mãe e senhora, este tênue, mas sincero e verdadeiro penhor da mais pura piedade e obediência filial e do mais eterno reconhecimento e gratidão, que vos dedica e consagra

Vosso

Muito amante e obediente filho,

A. L. S. Peixoto

* Publicação original: Considerações geraes sobre a alienação mental. Tese apresentada e sustentada a 29 de novembro de 1837 perante a Faculdade de Medicina do Rio de Janeiro, por Antonio Luiz da Silva Peixoto, natural do Rio de Janeiro. Doutor em medicina, e cirurgião aprovado pela mesma Faculdade. Rio de Janeiro, Typographia de L. A. Burgain, 1837.

A ortografia do texto foi atualizada e foram incluídas as emendas indicadas na corrigenda que acompanha a tese, e ainda feitas algumas correções de erros tipográficos evidentes. Revisão da transcrição e notas de Ana Maria G. R. Oda. 


\section{Introdução}

Querendo obter o honroso título de Doutor em Medicina, havíamos de mister, para esse fim, cumprir com um dever irrecusável da Lei, apresentando uma Tese para ser por nós sustentada perante a Faculdade de Medicina do Rio de Janeiro. Por muito tempo hesitamos em nos decidirmos pelo ponto a que déssemos preferência, para fazer o objeto da nossa dissertação.

Percorrendo o vasto campo das ciências médicas, aí deparamos com os conhecimentos com que os gênios mais transcendentes, os espíritos mais infatigáveis e os observadores mais atentos, as enriqueceram com uma clareza e precisão lógica que tanto honraram o nosso século, e dão uma prova irrefragável de progressivo desenvolvimento do espírito humano, e, cônscio de nossa escassa capacidade, temendo ir, com mal aparada pena, profanar tão sagrados primores da arte, permanecemos na nossa hesitação. Mas, de outra parte, o tempo instava; e, para satisfazermos aos desejos que tínhamos de adquirir um título em medicina, forçoso era correr ao imperioso chamado de nosso dever. Tal era o terrível dilema que se nos antolhava! Que fazer, pois? Decidimo-nos a cumprir com a obrigação que nos impuséramos, convencido de que, se com tal resolução íamos dar um público testemunho da nossa insuficiência e nulidade literária, também daríamos provas dos puros desejos que temos de, a custo de muito errar, irmos aprendendo, a fim de podermos um dia ser útil à nossa pátria e à humanidade.

Eis-nos, portanto, resignado a fazer a nossa dissertação, escolhendo para seu objeto a Alienação Mental. E que outra moléstia mais importante nos podia ocupar do que aquela que perverte e aniquila à espécie humana o que ela tem de mais precioso, tal é a ação fisiológica da inteligência? ... E cuja sede, natureza e tratamento, apesar dos repetidos esforços dos médicos mais recomendáveis por suas luzes e incansabilidade em propagar os conhecimentos da arte, ainda hoje é problemática?

Desde os tempos mais remotos, os médicos estudaram e procuraram explicar este lamentável desarranjo mórbido das faculdades intelectuais. Mas como fizeram eles? Procuraram acompanhar a natureza em suas observações, e delas dar razões fisiológicas? Recorramos à história, e dela colheremos que o estado da alienação mental foi por muito tempo influenciado pelos prejuízos e, por isso, era ela atribuída a causas sobrenaturais. Assim os antigos, não procurando definir nem estudar esta moléstia com exatidão, davam como causa de sua existência o demônio, espíritos animais no cérebro, através dos quais a alma não podia sentir nem pensar com precisão. Alguns, entre eles Sennert, Revière, Plater, Hearnius etc., faziamno consistir em uma indisposição ígnea e maligna dos espíritos, ou em um humor ou materia peccante, que convinha eliminar do cérebro; e para o conseguir, 
empregavam certos medicamentos que julgavam próprios a fortificar o cérebro e a razão. Enfim, para não nos tornarmos muito extenso, omitiremos um sem número de específicos misteriosos empregados por uma cega superstição no tratamento das moléstias mentais. Mas, honra seja dada ao nosso século, porque nos trabalhos ultimamente publicados sobre a alienação mental, os fatos são ditados pelo espírito da observação: a sua autoridade não poderá definhar, senão quando a natureza deixar de ser constante em suas leis; no entanto, que esses outros séculos remotos, tristes frutos do espírito de sistema, e contendo todas as loucuras de que era então suscetível o espírito humano, não poderiam ser hoje repetidos sem provocar o riso e um justo desprezo.

Tal era o estado de atrasamento em que se achava esse importante ramo da arte, quando Pinel, respeitável nosologista francês, a quem a humanidade deve tantos benefícios, procurou arrancá-lo do caos e barbaria em que se achava, dando um completo tratado dele com o título de Tratado médico-filosófico sobre a alienação mental, no qual, se não fez tudo quanto era desejado, o que não se pode conceder nas únicas forças de um homem, pelo menos orientou aos que, querendo seguir seu nobre exemplo, continuassem na observação e consignação dos fatos que ele encetara. E, com efeito, sucederam-lhe Esquirol, Franck, Rush, Foville, Georget, Dubois, Broussais, Andral e outros que, prosseguindo no estudo desta importante moléstia, se bem ainda não resolveram definitivamente o grande problema da natureza da lesão, sede e tratamento; todavia, deixam antever grandes esperanças de resultados bem-sucedidos.

É dos respeitáveis autores, que acabamos de citar, que colhemos as doutrinas inseridas na nossa dissertação: bem se deve supor que apenas seguimos mal e de longe os seus vestígios; não esperem, portanto, os nossos juizes e leitores acharem nela matéria nova, por isso que fora arrojo nosso se pretendêssemos avançar onde gênios tão sublimes pararam. É este o nosso proposto.

Nada mais anelamos, tratando desta triste moléstia, que instigar nos nossos colegas o desejo de adiantar os conhecimentos de uma afecção tão digna da meditação do médico, e que sendo tão comum na nossa queria pátria, o seu estudo desgraçadamente ainda se acha muito atrasado. Possa ela, portanto, merecer a sua aprovação, desculpando com a benignidade e proteção, que os distinguem, os erros que, estamos bem convencidos, nos escaparam; e, em retribuição, o nosso reconhecimento seria eterno. Terminaremos esta introdução citando a sentença de Ovídio, que tomamos por epígrafe - Da veniam scriptis quorum non gloria nobis, sed utilitas officiumque fuit. *

*A sentença está em Epistulae ex Ponto, livro III, IX, 55-56.

Em tradução aproximada: "Perdoe meus escritos, cujo objetivo não foi a minha glória, mas a utilidade e o dever cumprido por eles". (N. da R.) 


\section{Considerações gerais sobre a alienação mental}

A alienação mental, loucura, stultitia, vesania, furor, morbi mentales, alienatio mentis, é uma moléstia apirética do cérebro, ordinariamente de longa duração, com perturbação contínua ou intermitente das faculdades intelectuais e afetivas, algumas vezes parcial, com ou sem lesão das sensações e dos movimentos voluntários, e sem desordens profundas e duráveis das funções orgânicas.

A loucura tem sido classificada em diferentes espécies; todavia, a divisão hoje geralmente adotada é em mania, monomania, demência e idiotismo. Definimos mania, delírio geral, com agitação, irascibilidade e furor; monomania, delírio parcial, com abatimento, morosidade, e inclinação à desesperação. A monomania ainda se subdivide em amenomania, quando o delírio é alegre; e em tristimania (hipocondria ou lipemania) quando o delírio é triste, o que também tem o nome de melancolia; demência, obliteração ou debilidade acidental das faculdades intelectuais, a qual, quando provém dos progressos da idade, chama-se demência senil; idiotismo, obliteração ou debilidade congenial da inteligência.

Esquirol subdivide o idiotismo em idiotismo propriamente dito e em imbecilidade. Marca diferentes espécies de idiotas, conforme a obliteração intelectual é completa ou mais ou menos intensa, havendo assim em uns obliteração total das faculdades intelectuais e, por conseguinte, ausência de determinações, mesmo de necessidades. É a essa espécie que Dubois, em seu excelente Tratado de Patologia Geral, dá o nome de idiotas automáticos, que bem se pode denominar vegetativos. Em outros, a obliteração das faculdades intelectuais não é completa, mas sim levada a um alto grau de intensidade: estes têm determinações, porém impelidas só pela necessidade. A esta espécie o autor já citado denomina idiotas indistintos. Finalmente, Esquirol chama imbecis aqueles que, sem ter bastante inteligência para exercer as funções ordinárias da sociedade, são todavia suscetíveis de algum fundo de educação.

São estas as divisões e subdivisões mais geralmente adotadas, como dissemos. Passaremos agora a tratar das causas, sintomas, marcha, duração, terminação, diagnóstico, prognóstico, anatomia patológica, sede, natureza e tratamento da alienação mental.

\section{Etiologia}

Os médicos têm geralmente indagado com tanta mais atenção a origem das afecções da inteligência quanto, privados de princípios certos sobre a sua natureza e sede, contavam alcançar conhecimentos úteis no estudo exato de suas causas. É, 
certamente, muito importante remontar à origem das circunstâncias, que podem influenciar sobre a aparição das moléstias mentais, por isso que este conhecimento pode fornecer dados proveitosos para obter a sua cura.

As causas da alienação mental dividem-se em predisponentes e determinantes.

Causas predisponentes - Os climas, as estações, as idades, os sexos, os temperamentos, as profissões, o modo de vida influem muito sobre a frequência, caráter, duração, crises e tratamento da loucura: ela pode ser modificada pelos costumes, civilização, situação política dos povos etc.

Podem os climas ser causa da loucura, e assim, nos temperados, sujeitos a grandes variações atmosféricas, e principalmente nos que são de uma temperatura alternativamente fria e úmida, úmida e quente, a alienação é mais frequente. Se atendermos a esta última consideração, veremos que é ela uma das causas que influem no grande número de loucos no Rio de Janeiro, e tanto mais, quando vemos que a classe indigente da sociedade, por isso que tem menos meios de evitar as influências nocivas das variações atmosféricas, é a mais atacada da loucura. As estações também influem na aparição das diferentes espécies de alienação. Segundo Hipócrates, Areteu e Celso, a mania é mais frequente no estio e no outono, a melancolia no outono, e a demência no inverno. Concordamos com esta opinião, porquanto a experiência mostra que é no verão quando no nosso país aparece maior número de alienados, e quase todos os nossos loucos são maníacos.

Idades - Os meninos são isentos da loucura; entretanto, Esquirol cita um autor que diz ter observado um menino de dois anos, maníaco. O mesmo refere que foi confiado aos seus cuidados um menino de nove anos, que ficara alienado em consequência de uma febre atáxica que sofrera. Como quer que seja, estes casos aparecem raras vezes, e diremos que na idade entre 25 a 35 anos, em ambos os sexos, e em qualquer condição de vida, é onde mais frequentemente aparece a loucura. Nas mulheres é mais frequente que nos homens até a idade de vinte anos, e da de cinquenta por diante. Poder-se-á convencer desta verdade, atendendo-se a que as mulheres não poucas vezes a dificuldade do aparecimento das regras, por qualquer lesão orgânica do útero, a supressão dessas mesmas regras, as afecções histéricas, um amor contrariado, são causas da alienação, como faremos ver em outro lugar, e que ordinariamente estas causas existem com mais frequência antes da idade de vinte anos.

Sexos - Alguns autores asseguram que as mulheres são menos sujeitas à loucura do que os homens. Esquirol não é desta opinião, e diz que fazendo-se uma comparação rigorosa entre as estatísticas dos alienados de todos os países, o número das mulheres é maior que o dos homens; mas que esta diferença se aproxima da proporção que existe no estado geral da população. Crê, além disso, que o número das mulheres não é maior em todos os países; diz que na França, por exemplo, é mais considerável, e dá como causa os costumes e a educação, por isso 
que em Paris elas frequentam mais os espetáculos e os círculos, abusam da música, empregam-se na leitura de romances etc., o que as torna mais predispostas à perturbação da razão. Na Inglaterra, porém, onde os costumes e a educação das mulheres são mais austeros, o número dos homens alienados é maior. Quanto a nós, estamos inclinados a crer que a diferença do sexo pouco influi no aparecimento da loucura, e que pode ela acometer, em diferentes países, maior ou menor número de homens ou mulheres, segundo as circunstâncias de educação, costumes, profissão etc.; pois se na mulher existe predisposição de maior irritabilidade e menor desenvolvimento dos órgãos da inteligência, o que incontestavelmente contribui para a alienação mental, o homem, todavia, pelo lugar que ocupa na sociedade, exposto como é a um sem número de contrariedades, desconhecidas pela mulher, está por esta parte, mais sujeito a alienar. Não podemos dizer a que sexo pertence o maior número de alienados no Rio de Janeiro, porquanto não tendo nós ainda, infelizmente, estabelecimentos regulares para a cura desta enfermidade, impossível nos foi formar uma estatística que, ao menos, tivesse o vislumbre da probabilidade; todavia, cremos que o número dos homens é maior.

Temperamentos - Sendo muito difícil encontrar-se temperamentos simples na prática, é por isso quase impossível determinar, com precisão, o temperamento deste ou daquele indivíduo, e esta dificuldade ainda cresce quando se trata de um alienado, onde são tão variáveis as modificações que apresentam seus gestos, porte e fisionomia. Em todo caso, os autores concordam em que o temperamento nervoso predispõe mais à alienação mental, em geral, no entanto que o temperamento sanguíneo predispõe particularmente à mania; o nervoso, caracterizado por uma suscetibilidade que tudo irrita e exaspera, é favorável à monomania; o linfático pode-se encontrar nos maníacos e monomaníacos, mas então deve-se temer que se tornem dementes; na constituição apoplética, a cabeça grossa com diminuição no desenvolvimento das regiões frontais, e o pescoço curto, produzem a demência. Os idiotas e imbecis não apresentam um tipo certo de temperamento.

Profissão e modo de vida - As pessoas que se dão a estudos mui sérios e aturados, e se entregam ao fogo de sua imaginação, fatigando sua inteligência com grandes teorias e hipóteses, ou concentrando suas ideias sobre um só objeto, apresentam uma condição muito favorável a tornar-se alienadas. Dryden diz que os homens de gênio aproximam-se dos loucos. Se esse autor quisesse falar dos homens cuja imaginação é muito viva e desordenada, e que tem uma grande mobilidade em suas ideias, teria razão em compará-los aos loucos: mas querer dizer que uma grande capacidade de inteligência é uma predisposição à loucura, entendemos ser um grande erro, porque gênios mui profundos, grandes poetas, exímios pintores têm havido, no entanto, que conservaram a sua razão ilesa até a extrema velhice. A loucura é sempre mais frequente nos homens cujas profissões dependem das vicissitudes sociais; e por consequência, os cortesões, os homens que ocupam grandes 
empregos na sociedade, os ricos, os negociantes que fazem especulações arriscadas, os militares ludíbrios dos caprichos da fortuna, são mais sujeitos a esta moléstia.

As profissões que expõem o homem à insolação, aos vapores do carvão, tais como os cozinheiros, padeiros e mineiros, são predispostas também à loucura. Esquirol diz que o vapor do chumbo produz, na Escócia, uma mania particular, na qual os maníacos em seu furor mordem-se desapiedadamente; os paisanos escoceses dão a esta mania o nome de mill-reeck. O mesmo autor diz que os mineiros do Peru e do México são também sujeitos a uma loucura particular. Em suma, pode-se dizer, falando em geral, que as profissões próprias a excitar fortemente a ambição do homem e expô-lo às vicissitudes da fortuna, são as mais favoráveis para o aparecimento da loucura.

A passagem de uma vida ativa a uma passiva é causa poderosa da alienação mental; por isso alguns autores dão a ociosidade como uma das suas causas constantes. O aumento da civilização também concorre para aumentar o número de loucos; não porque os costumes sejam mais depravados, como creem alguns autores, mas sim porque a atividade da vida intelectual e os revezes da fortuna são tão frequentes no meio dos movimentos rápidos de uma civilização avançada, quanto são raros nas sociedades novas ainda, e pouco industrializadas, nas quais o homem tendo satisfeito suas necessidades físicas, tranquilo, como qualquer outro animal, dorme no sono profundo da indiferença, até que novas necessidades se façam sentir. Daí vem que nos campos há menos loucos que nas grandes cidades, e que os camponeses são mais propensos a loucuras religiosas ou eróticas, porque são elas provocadas por paixões simples, pelo amor, pela cólera, e por enfados domésticos; no entanto, que nas cidades é o mais das vezes produzida pelo amor próprio lesado, a ambição frustrada, os revezes da fortuna. É por isso que na Inglaterra, diz Esquirol, onde se acham reunidos todos os caprichos, onde as transações comerciais se aumentam progressivamente, e se arriscam em especulações longínquas, a alienação é tão frequente.

Uma educação viciosa pode ser causa da alienação mental. Pinel e Esquirol citam alguns fatos a respeito.

Os costumes também influem muito no desenvolvimento desta enfermidade. Por exemplo, o uso imoderado do vinho e das bebidas alcoólicas predispõe à loucura, enfraquecendo as faculdades intelectuais; e a isso atribui Esquirol metade das alienações na Inglaterra, onde até os primeiros homens do Estado se não pejam de um abuso que tanto avilta o homem, sendo assim, não deve estranhar que os suicídios sejam tão frequentes entre os ingleses.

Os prazeres venéreos, levados a excesso e sem escolha, degradam e enfraquecem a razão do homem: o celibato, sobretudo quando forçado, também concorre para aliená-la. Não há quem não tenha experimentado que as senhoras que envelhecem sem se casarem, tornam-se rabugentas, e depois muitas vezes monomaníacas; 
e assim sua imaginação enfraquecida lhes afigura fogo, ladrões, fantasmas, inundações etc. etc., e com tais visões incomodam durante a noite as pessoas da família.

As ideias de uma religião supersticiosa são também causa de loucura, e por isso na Itália a melancolia religiosa é muito frequente.

O onanismo, esse flagelo da espécie humana, é mais vezes origem da loucura do que se pensa, e este vício é mais funesto ao homem que à mulher. Se a continência, como dissemos, é causa algumas vezes da alienação mental na mulher, a libertinagem o é ainda mais, principalmente nas mulheres públicas.

Dizem alguns autores, que a forma do governo influi na produção da loucura. Somos deste parecer, pois, se pode influir sobre as paixões e costumes dos povos, não surpreenderá que também concorra para a alienação mental, por isso que muitas vezes é esta causada pelas paixões e pelos costumes. Além disto, Scott assegura que viu muito poucos loucos na China; muitos viajantes dizem que na Turquia e na Espanha o número dos alienados é muito limitado, do que se segue que nos países que gemem sob o jugo do despotismo, que sufoca as luzes e comprime as paixões, o número dos alienados é menor. De outro lado, o governo republicano ou representativo, dando mais liberdade à expressão dos pensamentos, e pondo as paixões mais em jogo, deve ser mais favorável ao desenvolvimento da loucura. Escrevemos este artigo para assinarmos mais uma causa da alienação mental, o que é de nosso dever como prático, e jamais com o intuito de encetarmos uma questão política.

Os efeitos das revoluções são também causas da loucura, por isso que trazem após de si a perda das fortunas e dos empregos a muitos indivíduos; os pais têm de lamentar a morte de seus filhos, estes a de seus pais, a esposa a do esposo etc. Não estranha, portanto, que os lamentáveis estragos e desordens que seguem as revoluções, sejam capazes de perturbar a razão humana. Esquirol, para dar força a esta causa, diz que o número dos alienados aumentou consideravelmente em Paris, depois da revolução de 1789; mas cremos que deve-se também ter em linha de conta o aumento progressivo da população, e os melhoramentos que os estabelecimentos dos alienados têm tido em Paris, depois que Pinel deu o impulso ao estudo e tratamento da alienação mental; e por isso, muitos loucos que, em outro tempo, teriam permanecido no seio de suas famílias, outros em conventos e prisões, se acham atualmente confiados aos cuidados da medicina nestes estabelecimentos, tanto públicos como particulares, nos quais podem-se formar estatísticas perfeitas; e como todos ali se acham, é por isso que parece ter o seu número avultado.

Todas as causas que acabamos de referir predispõem à loucura, e algumas a determinam. Passaremos a tratar das causas excitantes, que dividiremos em físicas e morais.

Causas determinantes físicas - Poucas moléstias há em que a influência hereditária esteja mais provada do que na alienação mental; e na verdade, em quase todas as famílias em que há alienado, ordinariamente não é ele o único: ou o pai, 
ou a mãe, ou algum de seus ascendentes, padeceu desta moléstia. No Hospital da Santa Casa de Misericórdia, houve um alienado que tinha um filho também louco, no mesmo hospital, e consta-nos que este sujeito tinha na Bahia outro filho com a mesma moléstia. Conhecemos uma família, no interior da Província do Rio de Janeiro, e aliás bem ramificada, da qual quase todos os membros, mais ou menos, padecem da loucura. Temos notícia de outra família em que existem dez filhos que todos são uns idiotas e outros imbecis: a mãe destes indivíduos e a avó eram também idiotas. Outros muitos fatos, não só no nosso país, mas ainda referidos em todos os autores que têm escrito sobre a alienação mental, provam quanto disposições hereditárias concorrem para o aparecimento da loucura, os quais não referiremos porque não haverá quem não esteja convencido desta verdade.

Diferentes moléstias do cérebro, a meningite, a encefalite, a histeria e a epilepsia, degeneram muitas vezes em moléstias mentais.

A epilepsia, particularmente, se termina pela loucura. Esquirol diz que de trezentos epiléticos que se achavam no hospital da Salpêtrière, mais da metade eram alienados, uns imbecis, outros dementes, alguns maníacos, e mesmo furiosos. Conhecemos um indivíduo afetado desta moléstia, o qual, depois dos acessos, torna-se imbecil por muitas horas; e à medida que estes se repetem, as faculdades intelectuais se lhe vão enfraquecendo e deteriorando. A histeria e a hipocondria também degeneram e passam muitas vezes à loucura. Isso tem feito confundir estas moléstias com a alienação mental, por um grande número de autores antigos e modernos.

A menstruação, que tem grande influência em quase todas as moléstias das mulheres, não pode ser estranha à produção da alienação mental. $\mathrm{Na}$ verdade, os esforços e os embaraços da primeira menstruação determinam a loucura. As desordens, a supressão e a cessação dos mênstruos provocadas, seja por causas acidentais, seja pela idade crítica, produzem a loucura. Esquirol refere o fato de uma moça que se achava demente havia dez anos, por efeito da supressão das regras: um dia, estas lhe apareceram, e logo recobrou o uso da razão. Cita outro exemplo de uma mulher que enlouqueceu na primeira menstruação, e ficou curada quando tocou a idade crítica.

A leucorreia, que muitas vezes é suplementária dos mênstruos, e a que as mulheres que têm uma vida sedentária são tão sujeitas, suprimindo-se causa também a loucura.

A supressão das hemorroidas é quase tão funesta aos homens, como a da menstruação às mulheres. É, no Rio de Janeiro, uma causa muito ordinária da perda da razão.

Os partos e a supressão dos lóquios ocasionam muitas vezes a loucura. Os efeitos desta causa são tão gerais e conhecidos, que nos dispensamos de citar exemplos. 
A supressão de dartros, em ambos os sexos, a da transpiração, do corrimento nasal, das blenorragias, de uma úlcera, de um exutório, repercussão da sarna e da gota, são muitas vezes causas da alienação mental.

Finalmente, pode a loucura ter outras muitas causas, e no número delas notaremos as febres de mau caráter, algumas afecções crônicas, o abuso e mesmo o uso de medicamentos excitantes, que obram fortemente sobre o sistema nervoso etc.

Tais são, em geral, as causas físicas da alienação mental. Trataremos agora das morais, que contribuem mais comumente para a produção da loucura, do que aquelas.

Causas determinantes morais - Empresa temerária seria pretender traçar um quadro completo das causas morais da loucura. Não há, talvez, circunstâncias na vida que não se possam tornar causas da alienação mental. Certamente, não haverá quem negue que muitas vezes a mais simples impressão é capaz de produzir a alienação mental, e mui principalmente em um indivíduo a quem afeta uma indisposição física, o que bem prova quanta influência tem o físico sobre o moral, verdade esta exuberantemente demonstrada por Cabanis. Todavia, as causas mais frequentes são as emoções vivas, o terror, o amor levado a excesso ou contrariado, o temor, a cólera, a ambição, os revezes da fortuna e os desgostos domésticos.

Deveríamos ter classificado esta última causa em primeiro lugar, por isso que é a que mais comumente produz a loucura, se o vocábulo encerasse uma ideia simples; mas, por desgostos domésticos, exprimem-se todas as aflições, dores, infortúnios e dissensões de família. Não se faz certamente, uma justa ideia do quanto isto obra sobre o homem. Esquirol, em um extrato que dá sobre os alienados da Salpêtrière, diz que de 323 que ali se achavam, 105 contavam por causa desgostos domésticos, pelo que se vê que está na relação de três para um.

As primeiras necessidades do homem, limitando-se à sua conservação, não lhe despertam senão determinações do instinto; porém, mais tarde a razão se desenvolve, aparecem os desejos, estes produzem paixões, e estas necessidades que não têm relação alguma com a nossa conservação, são o fruto da nossa inteligência desenvolvida, e da civilização; e eis o motivo porque os autores concordam em dar a atividade forçada da inteligência nos progressos da civilização, como causa da alienação mental; eis, portanto, também a razão porque a infância é isenta da loucura.

Esquirol diz que as paixões alegres são raramente a causa desta moléstia, e mesmo parece duvidar de que jamais o sejam, se dermos atenção a esta sua frase: "É singular que um excesso de alegria, capaz de matar, não roube a razão, no entanto que um dissabor provoca tantas vezes a perda dela." Apesar do respeito que tributamos às luzes de Esquirol, não concordamos com a sua opinião, porquanto não podemos crer que uma paixão alegre, que, como ele diz, mata, não seja capaz de produzir alienação. Não diremos que seja tão constante como as que provêm 
das sensações tristes, mas seria muito degradar a espécie humana dizer-se que só paixões tristes, motivos de ambição, amor próprio ofendido etc., são capazes de perturbar a sua razão.

Algumas causas morais se combinam ordinariamente com as físicas, particularmente nas mulheres, e produzem a alienação mental. Todos os dias encontram-se casos desta natureza.

\section{Sintomatologia}

Três ordens de sintomas se declaram na alienação mental, e são: simples perturbação das faculdades intelectuais, complicação desta com a das sensações, ou com a dos movimentos. Trataremos em primeiro lugar dos sintomas da alienação com simples perturbação das faculdades intelectuais.

São tão numerosos, quantas as combinações possíveis do pensamento; tão diferentes como nossas paixões, educação, prejuízos e afeições. "Quem poderá, diz Esquirol, se lisonjear de ter observado e poder descrever todos os sintomas da mania, mesmo em um só indivíduo?". E, com efeito, como notar as modificações fugitivas e multiplicadas de um delírio geral? Como aprofundar as infinitas sutilezas de um delírio parcial? Em um delírio geral, as ideias mais extravagantes, as imagens mais bizarras, as comparações mais disparatadas, as paixões mais opostas se sucedem com uma rapidez elétrica. $O$ insensato confunde, em seu espírito, o céu, a terra e o inferno; seus negócios domésticos, seus afetos, a política e a moral. Fala em verso, canta, ri, chora e recita sentenças com um tom enfático: enuncia-se nas diversas línguas que sabe, dirige-se a um indivíduo, que falar-lhe, mas de repente retrocede sobre seus passos; levanta as mãos ao céu, lança-as à direita e à esquerda, dança, salta, dá gritos ameaçadores, arroja-se sobre seus companheiros de infortúnio, quebra tudo o que se lhe apresenta, põe-se nu, rola sobre a terra etc. Nestes casos, a ação de órgão do pensamento não se acha destruída, mas sua atividade desregrada já não é análoga às operações regulares do nosso espírito; assim como as convulsões espantosas de um epilético não se assemelham ao pacífico andar de um homem com saúde.

Que diferença no delírio parcial! Suponha-se Newton aplicado à solução de um grande problema, reunindo todas as forças de seu gênio para descobrir razões poderosas à sua demonstração; ainda assim não se terá uma ideia justa da imperturbável atenção de certos delírios parciais e dos infinitos recursos que buscam os doentes para justificar seus erros. Eis como se exprime Foville, para mostrar a dificuldade que se encontra em notar todos os sintomas que apresenta um alienado entregue ao rigor do seu delírio. O delírio geral é mais comum quando há desordens 
nas faculdades intelectuais propriamente ditas; o parcial é o mais das vezes relativo aos afetos, e neste casos a inteligência é intacta debaixo de muitas relações. Nos delírios gerais se observa ordinariamente grande agitação. Muitos doentes gritam dia e noite, e é por isso que sua voz é tão alterada que se não pode ouvir a alguma distância. Ainda que isso dependa em parte dos gritos, todavia, parece que este sintoma se apresenta por uma influência nervosa especial, por isso que em muitos esta afonia se declara logo nos primeiros momentos da loucura.

Um sintoma mui particular, e que se nota muitas vezes, é que os alienados repetem os seus gestos, discursos e ações duas e mais vezes: muitos tomam aversão aos seus parentes e amigos, e os consideram como seus perseguidores. Estes sintomas notam-se mais particularmente nos alienados perseguidos de falsas percepções, como faremos ver em outro lugar. Em suma, já fizemos sentir a diversidade de sintomas que observa quem entra em uma casa de alienados. Neste triste recinto, onde a vaidade se patenteia com todos os seus ridículos, acham-se soberanos, príncipes, grandes dignatários e até deuses; grandes questionadores, orgulhosos, ladrões, astuciosos e assassinos também ali se encontram. Uns imploram a morte porque se veem perseguidos, outros julgam-se desgraçados; finalmente, cada um tem seus costumes, inclinações, objetos de adoração etc.; Alguns não dizem palavra nem se movem, outros andam e falam constantemente e nada dizem. Estes são pintores, músicos e artistas, aquele é poeta, faz versos; no entanto que, no uso de sua razão, não tinha inclinação alguma à poesia; há também visionários de toda a espécie. Muitos se dão ao estudo das ciências naturais: Foville, no seu artigo sobre a alienação mental, no Dicc. de Med. e Cir. Prat., ${ }^{*}$ diz que possui um manuscrito muito longo, composto por um alienado, sobre a formação do globo e suas evoluções, e que as mais importantes questões de metafísica, religião e astronomia ali se acham discutidas e resolvidas. Finalmente, para terminarmos este artigo, lembraremos um caráter notável dos alienados, e é que eles não têm a consciência do seu delírio, e acusam de doidos aqueles que dizem que a sua razão se acha alienada. Este conhecimento julgamos muito importante para alguns casos de medicina legal.

Quando nas moléstias mentais há complicação de desordens nas percepções, novos sintomas se declaram. Todos os insensatos que experimentam falsas percepções, ou seja porque em consequência de uma lesão dos órgãos dos sentidos, se lhes transmitem ao cérebro impressões falsas; ou seja porque estas percepções não se apresentem à sua imaginação transmitidas pelos órgãos dos sentidos (alucinação); então no seu delírio não estão só em relação com o mundo exterior, julgam-se

* Dictionnaire de médecine et de chirurgie pratiques, editado por Gabriel Andral. Sobre o uso desta fonte, ver o texto de apresentação à tese de Peixoto. (N. da R.) 
provocados por vozes e insultos, cujos autores não descobrem, e por objetos espantosos que se apresentam à sua vista; são atormentados por cheiros infectos etc.: eles reagem, cada um segundo o número e força de ideias que o ocupa, contra essas falsas sensações. No Hospital de Santa Casa da Misericórdia, observamos muitos destes infelizes perseguidos por erros dos sentidos e por alucinações; há ali um que traz quase sempre os ouvidos e ventas tapados, e que, diz ele, o faz para subtrair-se a maus cheiros e vozerias que o costumam perseguir. Aí existe outro maníaco, que constantemente agride contra pessoas que o insultam, no entanto que sempre se acha solitário. Quando há esta perturbação nas percepções dos alienados, o furor do maníaco e do monomaníaco, nutrindo-se de seus erros, não encontra limites; então invocam os tribunais, o ferro, o fogo, o cadafalso, para punir a barbaridade de seus secretos perseguidores. Muitas vezes incendeiam sua própria casa para queimar feiticeiros que a habitam. É muito comum ouvi-los dizer que o que eles ouvem, sentem etc., não pode ser sentido pelas pessoas com quem se acham, pelo poder dos mágicos. Podia-se encher muitos volumes, referindo-se cenas trágicas que muitas vezes esses infelizes realizam, perseguidos de falsas sensações. Mas, quando a sensibilidade diminuída dos doentes tem embotado suas sensações verdadeiras ou falsas, quando a degradação progressiva de sua inteligência já lhes não permite ativas combinações do pensamento, então vivem a murmurar surdamente suas queixas, e se entretêm em baixa voz com as que eles pensam lhes falam. Muitas vezes as percepções falsas lhes vêm por alteração nos órgãos dos sentidos, e nestes casos basta tapar-se-lhes os olhos, boca e ouvidos, para cessar o seu delírio. Reil e Esquirol citam exemplos deste gênero. Estes erros das sensações ordinariamente só afetam um sentido, algumas vezes dois, três ou mesmo todos; porém, este último caso é muito raro.

Outras vezes, os alienados padecem de falsas percepções, sem terem lesões dos órgãos destinados a transmitir as impressões ao cérebro, e é o que propriamente se chama alucinação. A maior parte dos alienados que têm alucinações são mais perseguidos delas nas trevas e na solidão, quando os sentidos estão em um estado completo de repouso: nestes casos, os cegos e surdos oferecem alucinações do ouvido e da vista. Foville refere o caso de um eclesiástico que sofria alucinações do ouvido, e ouvia constantemente vozes que o insultavam e ameaçavam lançá-lo fora de casa, o ilustre autor diz que procurou inspirar-lhe dúvidas sobre a realidade das injúrias e ameaças que ele acreditava ouvir, recordando-lhe o que teria lido sobre os erros dos sentidos, ao que ele respondeu: - Está bem, já que tudo quanto ouço provém de erros dos sentidos e de tudo devo duvidar, então, também duvidarei do que me dizeis, de que vos vejo, de que vos ouço etc.

A perturbação das faculdades intelectuais pode ser também complicada por percepções falsas da sensibilidade geral. Neste caso estão os alucinados que acreditam ter na cabeça, no ventre etc., o diabo e animais que os devoram. Estas falsas 
percepções podem também ser referidas pelos alienados a partes de seu corpo que se achem lesadas. Esquirol cita o fato de uma mulher que se queixava de ter o diabo no ventre, e que, dizia ela, lhe tinha colocado uma corda desde o púbis até o esterno, que lhe causava grandes dores e vedava-lhe o andar. Esta infeliz morreu, e a autópsia demonstrou grandes alterações de pericárdio, coração e peritôneo. Vê-se que nessa alienada as dores motivadas pela pericardite e peritonite, é o que ela atribuía à obra do demônio.

Os alienados apresentam ainda outras lesões da sensibilidade. Alguns se mordem desapiedadamente, sem manifestar a menor dor; outros comem os excrementos, palha e erva, com uma avidez espantosa. Foville cita muitos casos desta natureza, e tivemos ocasião de observar o mesmo em um idiota no Hospital da Santa Casa da Misericórdia. É aqui que convém falar dos alienados que têm a faculdade de sofrer os extremos de um calor ardente e de um frio rigoroso. Rush cita o exemplo de uma alienada que dormia toda a noite sobre uma pedra, em tempo de frio o mais rigoroso, sem experimentar indisposição alguma. Foville refere outro análogo a este. Muitos se expõem aos ardores do sol, fixam a vista sobre este astro por horas seguidas sem manifestar a menor sensação. Terminaremos lembrando que os alienados acometidos de falsas percepções são muito perigosos, e por isso deve-se ter uma vigilância ativa sobre eles, porquanto muitas vezes, na força de suas alucinações, ouvem vozes que os mandam, em nome de Deus, cometer assassínios, incêndios etc. e não podendo subtrair-se à obediência, o executam, se não encontram quem lhes ponha obstáculos.

Quando desordens nos movimentos se complicam com as perturbações das faculdades intelectuais, uma terceira ordem de sintomas se oferece. Estas desordens são de duas espécies: uma consiste na alteração passageira e local, outra na geral e persistente dos movimentos voluntários. Os movimentos em muitos alienados adquirem uma energia extraordinária: têm uma necessidade irresistível de correr e saltar; estes fenômenos, produzidos pela irritação geral que a lesão do cérebro determina, não podem, sem dúvida, ser olhados como uma alteração especial, porque, se bem algumas vezes movimentos irregulares, e como que convulsivos, se manifestem durante os paroxismos da alienação, na face, em um braço, e em uma perna; todavia, eles se distinguem das convulsões que se observam nos epiléticos, histéricos etc., as quais obram em todo o sistema muscular. Parece, portanto, que esta agitação desordenada provém do trabalho mórbido do cérebro, de que resultam os acessos de loucura.

Uma alteração ainda mais grave e muito comum vem complicar-se com a alienação. É da paralisia, chamada dos alienados, que queremos falar. Consiste ela no enfraquecimento geral e gradual dos músculos submetidos à vontade. Os antigos nada disseram sobre esta alteração: foi Pinel o primeiro que falou nela, e depois 
Esquirol, Bayle, Delaye e Calmeil, continuaram a estudá-la, e todos eles referem numerosas observações em seus trabalhos sobre este objeto. Esta alteração se manifesta a princípio por um embaraço nos movimentos da língua. Foville diz que é possível que ela principie logo nas pernas e nos braços, sem ser apreciada pelo observador, no entanto que, quando os movimentos da língua não têm a precisão normal e a pronunciação se altera, é que o médico presta atenção a esta desordem. Como ainda não fizemos observação alguma a este respeito, não podemos assegurar qual é a primeira parte afetada. Como quer que seja, o diagnóstico desta lesão é muito difícil no princípio; só um médico bastante exercido é que pode atinar com o começo da paralisia. Mas, quando este sintoma faz progressos, o embaraço na pronunciação é muito sensível, o doente não pode falar sem que não se ponham em contração os músculos da face, a progressão é incerta e vacilante, os movimentos do braço pouco seguros, as mãos tremem constantemente e não pode conservar uma posição determinada.

A marcha desta complicação oferece dois períodos bem distintos. No primeiro, os movimentos, bem que irregulares, nem por isso perdem a sua força, porque os doentes apertam vigorosamente qualquer objeto na mão, no entanto que não se podem dar a um trabalho delicado, v.g., enfiar uma agulha, aparar uma pena etc.: correm um espaço muito considerável, mas a sua carreira é irregular. No segundo período, a este vigor no sistema muscular vai substituindo uma certa rigidez, que acaba finalmente por um relaxamento e apatia progressivamente aumentada. Então, quando este lamentável estado se declara, os doentes não são capazes de algum esforço; os traços fisionômicos se alteram, as pálpebras se entreabrem penivelmente, as maxilas se afastam, os lábios perdem a sua contratilidade; as dejeções fazem-se involuntariamente. Estes infelizes, tendo uma grande dificuldade em se mover, permanecem constantemente assentados, ou antes, deitados. Finalmente, a morte vem finalizar o estado agonizante e enternecedor destes entes desgraçados da espécie humana, para quem a vida já é um peso insuportável. Em suma, é nesta classe que se funde e desaparece a maior parte dos sintomas característicos das divisões da alienação, em mania, monomania etc. A uniforme demência caracteriza o maior número de alienados que ficam paralíticos; e se no princípio desta afecção apresentam algumas aparências de delírio, reconhece-se sempre o cunho da demência profundamente impresso nele. O seu delírio, semelhante a uma fraqueza senil, ou a um sonho, é caracterizado pela incoerência e aborto de suas ideias, não tem aquele tipo de firmeza, convicção e pertinácia dos monomaníacos; nem a violência, atividade e sucessão rápida de ideias de um maníaco. É mais comum ver o paralítico chorar do que vê-lo reputar-se uma grande personagem; e se ideias de grandeza, títulos e riquezas lhe passam pela mente, são momentâneas, e as exprime com o acento da demência. 
Outros sintomas acessórios e gerais da alienação mental. Os alienados padecem uma insônia teimosa, principalmente se a alienação é recente. As conjuntivas se acham ordinariamente injetadas, o pavilhão das orelhas é de um vermelho intenso. A expressão da face está em relação com a natureza das paixões que os dominam; a sua cor não é sempre a mesma, algumas vezes é de um vermelho escarlate, outras pálida e lívida. A pele é quente e seca; outras vezes quente e úmida. Ordinariamente conservam um grande calor na cabeça, no entanto que as extremidades quase sempre estão frias.

De ordinário não se nota movimento febril nos alienados; todavia, em alguns o pulso é aumentado, principalmente nos maníacos, e quando a enfermidade reconhece por causa lesões do cérebro, ou de algum outro órgão. Rush quer que esta afecção produza no maior número de casos a pirexia, e, em apoio da sua opinião, diz que observara aumento de pulso nos $7 / 8$ dos seus doentes alienados. Sem contestarmos a exatidão dessa asserção de Rush, lembraremos, em primeiro lugar, que é preciso distinguir a mera frequência do pulso de uma verdadeira pirexia, e em segundo, que restaria saber se esses indivíduos padeciam ou não de alguma lesão estranha à alienação mental, e bem assim se a loucura era ou não o resultado dessas afecções. Como quer que seja, o que é averiguado, é não ser a pirexia um sintoma essencialmente ligado à simples afecção da inteligência, sem que por isso ela deixe de verificar-se em alguns casos, particularmente naqueles que acabamos de mencionar.

Os movimentos do coração são mais fortes; muitas vezes sintomas de hipertrofia, de dilatação do ventrículo esquerdo do coração, ou de outras alterações do órgão central da circulação, existem no maior número de alienados. Foville diz que nas autópsias por ele feitas encontrou alterações deste gênero em mais de 5/6 dos cadáveres.

A digestão é ordinariamente perturbada nos primeiros dias da alienação, a boca apresenta-se saburrosa, a língua coberta de um indulto esbranquiçado; o apetite é nulo e a sede intensa. Ordinariamente a constipação de ventre é um sintoma constante da alienação, e muitas vezes persiste enquanto dura a moléstia. Em suma, em muitos alienados se declara uma espécie de salivação habitual.

Temos tratado em geral dos sintomas principais da alienação mental, tirados dos diferentes aparelhos: eles existem nos alienados cujas sensações e movimentos se exercem tão regularmente como no estado de saúde. Os únicos constantes são as perturbações das faculdades intelectuais.

Agora trataremos de uma maneira geral dos sintomas particulares da mania, da monomania, da demência e do idiotismo.

$\mathrm{Na}$ mania o delírio é geral, os acessos de furor são assaz comuns, a agitação física é constante; há insônia frequente, principalmente no princípio. A fisionomia dos maníacos oferece sempre uma expressão forte, seus olhos são brilhantes e 
móveis, a figura é animada, o pescoço como que inchado, e as jugulares distendidas. Este estado, que se nota no pescoço e nas jugulares, é a consequência das repetidas vociferações destes indivíduos. A voz dos maníacos é rouca e obscura; o pulso é febril, a pele quente e seca ou úmida, a temperatura é tão aumentada na cabeça, quanto baixa nas extremidades inferiores. $\mathrm{O}$ apetite perde-se ordinariamente nos primeiros tempos da mania, a sede é intensa, a língua seca e coberta de um indulto esbranquiçado, e há constipação de ventre teimosa. No fim de um ou dois septenários da moléstia, estes sintomas e desarranjos dos órgãos digestivos desaparecem, e o apetite torna-se natural, o que é de mau agouro para a cura, se o maníaco não tem apresentado melhoras nos desarranjos da inteligência.

Na monomania o delírio é parcial ou circunscrito a um pequeno número de objetos. Ela, em seu estado mais simples, é rara; os doentes que deliram em um único objeto são muito poucos: muitos confundem nesta denominação todos os alienados que têm uma ideia dominante habitual. Foville diz que em todos os doentes de um hospital, confiados aos seus cuidados, ele só achou dois que merecessem rigorosamente o nome de monomaníacos.

Todos os autores que têm escrito sobre a monomania, a tem distinguido segundo a ideia dominante do seu delírio. Em alguns indivíduos o delírio é alegre (amenomania), eles se julgam reis, imperadores, papas, profetas, rainhas, princesas e as suas ações se acham em relação com esta crença; outros se queixam com o acento da desesperação por haver perdido a amizade de pessoas que lhes são caras. Alguns se ocupam da ideia de um objeto que adoravam e no qual falam continuamente (erotomania); outros são atormentados por escrúpulos religiosos e perseguidos pelo temor do inferno (monomania religiosa); muitos se creem em poder do diabo (demonomania). Em certos monomaníacos a tristeza, o enfado e desgostos são os sintomas dominantes (melancolia, lipemania de Esquirol); chama-se panofobia o estado habitual do temor e terror; misantropia, o de ódio a seus semelhantes. Há alguns que se julgam transformados em um indivíduo de outro sexo, em um cão, em um pássaro etc. (zoantropia, licantropia). A monomania consiste algumas vezes na exaltação mórbida de certos talentos, e assim alguns são músicos, poetas etc.; muitas vezes, enfim, é acompanhada do desejo da própria destruição (melancolia suicida); ou desejos de matar a outrem (monomania homicida); outros desejam atear fogo aos edifícios (monomania incendiária). Enfim, nas mulheres, se declara às vezes um desejo violento e irresistível de satisfazer aos prazeres venéreos e é isso uma espécie de monomania conhecida debaixo do nome de ninfomania. Um estado análogo se manifesta no homem, o que se chama satiríase. As alterações que a fisionomia, o pulso etc., dos monomaníacos apresentam estão em relação com a natureza do delírio que os domina.

A demência sucede ordinariamente à mania, ou à monomania, ou é o efeito dos progressos da idade, e então é primitiva (demência senil). Seus principais 
caracteres são o enfraquecimento ou a perda das faculdades intelectuais. Os dementes parecem não ter nem ideias, nem necessidades, nem desejos. Seus traços fisionômicos são inteiramente decompostos, os músculos da face relaxados, e seu olhar é incerto; não escutam nem falam; riem-se ou choram sem motivo; sua pele parece pouco sensível. Eles permaneceriam dia e noite expostos ao tempo, se os não tirassem desse estado de apatia. Em suma, estes doentes vivem concentrados em si mesmos, sem proferir uma só palavra, por diferentes motivos: um pensa que morre se falar, outro recebe ordens secretas de calar-se etc. Se eles chegam a curar-se, dizem que sentiam e pensavam, mas que não tinham o poder de queixar-se. Esquirol refere que tratara de uma demente que apresentava uma insensibilidade mui grande na pele, de modo que era indiferente a todas as experiências dolorosas a que a submetiam. Esta mulher curou-se, e soube-se então dela que sentia as experiências que se lhe faziam, mas que uma voz superior, e à qual não podia resistir, lhe ordenava que se calasse. Finalmente, nesses indivíduos as funções orgânicas tornam-se tanto mais ativas quanto as intelectuais o são menos. Tem muita disposição a engordar, e são geralmente imundos. $\mathrm{O}$ que dissemos da demência pode-se dizer do idiotismo, com a diferença, porém, que aquela provém da obliteração ou enfraquecimento acidental da inteligência, no entanto que este é primitivo ou cogenial. Acrescentamos que um caráter particular dos idiotas, é que eles em geral são mui astuciosos, ladrões, libidinosos e imorais, têm bastante sagacidade para enganar e iludir qualquer pessoa.

\section{Invasão, marcha, duração e terminação}

A invasão da alienação mental é rápida ou lenta; no primeiro caso, isto é, se a causa é violenta, ela se declara sem ser precedida de pródromos ou sintomas precursores; no segundo, estes aparecem preliminarmente, o indivíduo sente cefalalgia, insônia, muitas vezes uma agitação constante e um movimento febril aparecem; os seus hábitos mudam e as suas ações não são conformes às que praticava antes; qualquer dito ou ação de seus parentes e amigos o exaspera. Muitas vezes tem consciência do estado desordenado de sua razão, e procura mesmo descobrir nos olhos das pessoas que o cercam, o juízo que fazem da sua inteligência. Alguns há que acham bastantes recursos para ocultar o desarranjo de suas ideias. Outros, mais francos, dizem que vão perder o juízo. Em suma, esta espécie de incubação dura até que uma causa excitante, ou qualquer acidente, determina a loucura, de sorte que, quando a moléstia se declara e chega a ser conhecida pelos parentes e amigos do indivíduo, examinando-se suas ações anteriores, ver-se-á que data de mais tempo a loucura. Se a invasão é lenta, a moléstia se declara de noite, a menos que qualquer acidente venha antecipá-la. 
A alienação mental pode ser idiopática, simpática e sintomática. É simpática, por exemplo, se aparece durante a prenhez ou em consequência de partos (alienação puerperal); sintomática, se é o resultado de um tumor desenvolvido no cérebro, e que, comprimindo-o, produz a obliteração lenta e gradual da inteligência etc. Pode reinar epidemicamente se, sendo a causa geral, obra sobre muitos indivíduos, tais são os efeitos das revoluções, as calamidades públicas etc. É contínua ou intermitente. A contínua tem uma marcha regular e constante, e um espaço de tempo a percorrer, mas oferece algumas vezes uma remitência (é o que se chama momentos lúcidos), que duram algumas horas, e mesmo alguns dias; porém, o calor que os alienados conservam na cabeça, o estado dos olhos, e uma certa exaltação, bem indicam que isto apenas é um alívio passageiro. Este fenômeno se observa mais vezes nos monomaníacos, quando eles podem se esquecer por um momento da ideia dominante que os ocupa. Algumas vezes esta remitência constitui um estado de transição de uma espécie de alienação a outra; assim, diz Esquirol, um alienado passa três meses na monomania, três na mania, três, quatro ou mais na demência, e assim sucessivamente. Observam-se casos análogos entre nós. A alienação intermitente, porém, difere da remitente, em que as funções todas entram em seu estado normal, a razão é tão perfeita, o juízo tão forte, e o sentimento de interesses tão seguros como no estado de boa saúde. A intermitência é umas vezes regular e outras irregular; no primeiro caso, os indivíduos passam 15 dias alienados e outros $15 \mathrm{com}$ perfeita saúde; outros são atacados na mesma estação, na mesma época do ano etc.: no segundo, varia muitas vezes no mesmo indivíduo, e pode durar dias, meses e anos.

A duração da alienação mental é mui variável; pode durar 15 dias, um, dois, três, cinco meses, mesmo um ano e mais; todavia, o termo médio é de sete meses a um ano. Quando excede deste tempo, e principalmente do segundo e terceiro anos, então passa ao estado crônico, e ordinariamente é incurável: se bem há casos de alienados que têm se curado depois de cinco, dez e mesmo vinte anos, eles são raros, e observam-se particularmente quando a loucura tira origem de uma lesão de qualquer órgão, a qual cessando, a razão pode se restabelecer.

A alienação termina-se pela cura, passagem ao estado crônico, ou pela morte. A cura pode se efetuar, ou recobrando a razão gradativamente todo o seu império, ou momentaneamente. Neste caso, a cura coincide ordinariamente com a aparição de fenômenos chamados críticos. "Algumas vezes, diz Foville, é uma salivação abundante, o aparecimento de um enfarte das parótidas, o desenvolvimento de uma enorme quantidade de furúnculos à superfície do corpo, a volta de um corrimento hemorroidal, a das regras, uma diarreia abundante, suores copiosos, que determinam a cura da alienação mental".

Muitos autores não admitem a doutrina das crises na alienação mental; mas acreditamos que ela tem suas crises, as quais muitas vezes determinam-lhe a cura; 
todos os dias estão se vendo exemplos desta natureza. Alienados que sofriam da supressão da menstruação, de transpiração, de salivação, de um fluxo hemorroidal, de dartros, sarnas etc. etc.; quando estas supressões cessam, coincide esse fenômeno com a sua cura. Acreditamos mesmo que ela é mais perfeita quando coincide com um destes fenômenos críticos.

Suscita-se uma questão, e é saber se as afecções morais, reagindo sobre a sensibilidade, modificando as sensações, as ideias e as determinações dos alienados podem ser consideradas como críticas da loucura, da qual elas são tantas vezes a causa. Esquirol é desta opinião. Pergunta ele: "Uma alegria imprevista, um sucesso inesperado, não têm feito cessar moléstias as mais graves? Não acontece todos os dias que um vivo terror, ou um violento desgosto ocasionam, moléstias reputadas incuráveis? Não se assemelham aos movimentos tumultuosos, que precedem as crises físicas, estas perturbações que se levantam no homem moral?". Não se pode deixar de responder afirmativamente às perguntas do ilustre médico francês, e por isso não se deve recusar a influência das afecções morais à solução da loucura, quando se lhes concede uma tão poderosa para a conservação da saúde; para a produção das moléstias, particularmente nervosas e sobretudo a loucura. Além disto, esta verdade é confirmada pelos efeitos salutares que se colhem dos choques morais, no tratamento da alienação mental, como faremos sentir no lugar próprio.

A loucura complica-se muitas vezes com o escorbuto, a epilepsia, a hipocondria, a histeria etc.; ou seja que estas moléstias obrem como causas, ou seja, que marchem simultaneamente com ela. Pode também complicar-se com outras moléstias graves, que, ou a suspendam, ou a façam cessar, ou determinem a morte do alienado. Foville e Esquirol referem muitos casos deste gênero.

Há alguns alienados que só podem curar-se até certo ponto: eles tornam-se de uma suscetibilidade tal, que as mais ligeiras causas provocam recaídas; nestes casos, eles só podem conservar a sua razão, permanecendo onde nenhum choque moral, acontecimento ou inquietação, os exponha a recair em seu primeiro estado. Mas outros ficam perfeitamente curados: entram no exercício de suas funções, tornam a adquirir seus hábitos, profissões, modos de vida etc. Em todo o caso, porém, estes indivíduos não deixam de conservar uma certa suscetibilidade, e por isso convém toda a cautela para evitar a recaída. É sabido de todos que os indivíduos que padecem de febres, inflamações etc., estão mais predispostos a contrair novamente estas mesmas moléstias do que aqueles que ainda não foram afetados por elas; porquanto um órgão, uma vez afetado, está por isso mesmo mais disposto que um outro a sê-lo de novo. Ora, se isto é verdade a respeito das moléstias em geral, com muito mais razão deve ser a respeito da alienação mental que, além de ser uma afecção essencialmente nervosa, conta por causas um sem número de circunstâncias, que a cada passo da vida se reproduzem. É por isso que nos ricos as recaídas são mais raras; eles têm mais meios à sua disposição para evitá-las, no entanto, que as misérias do pobre o expõem 
a toda a força de sua ação. Finalmente, devemos lembrar que os alienados, quando se curam, conservam um sentimento penível de sua moléstia, e por isso é mui prudente evitar a recordação do seu antigo estado, porquanto pode mui facilmente perturbar-se-lhes de novo a razão, do que há exemplos. Quando a alienação termina passando ao estado crônico, qualquer que seja a sua natureza, quero dizer, ou seja monomania, ou mania, ela toma o caráter da demência. Os alienados podem viver muitos anos neste estado, a menos que a paralisia venha complicar-se com ela, porque, neste caso, em geral, não duram mais que um ano.

A mortalidade nos alienados varia segundo a espécie de alienação; e assim ela é menor na mania, maior na monomania, e ainda maior na demência. Esquirol diz que a mortalidade na mania é de um sobre vinte e cinco; na monomania, de um sobre dezesseis, e na demência, de um sobre três. No Rio de Janeiro, a proporção é quase a mesma, segundo as observações do Sr. Dr. de Simoni. Morrem mais alienados no primeiro e no segundo ano da moléstia, e muito principalmente no primeiro: excedendo a esse tempo, e por conseguinte passando ao estado crônico, ordinariamente é raro que os loucos morram da moléstia mental: lesões do tórax e do baixo ventre, as febres atáxicas e adinâmicas, a apoplexia, o escorbuto etc., vêm se complicar com a alienação, e a estas enfermidades sucumbem.

\section{Diagnóstico}

O diagnóstico da loucura nem sempre é muito fácil. Quando o delírio é intenso e geral, ninguém se pode enganar; mas, quando parcial, há dificuldade muitas vezes em reconhecer a moléstia. Alguns alienados têm bastante discernimento para ocultar o estado de desordem de sua razão: eles procuram mesmo provar, por meio de argumentos, aliás muito convincentes, que não estão doidos; que os dão por tais para lhes roubarem o uso dos seus direitos civis etc., e o médico pode ser enganado por muito tempo, e só por uma observação de todos os momentos poderá encontrar provas e convencer-se do desarranjo parcial da sua razão. Outras vezes, um malfeitor, para subtrair-se à punição de um delito, finge-se alienado, e pode o fazer com tanta destreza e sagacidade, que o médico se achará embaraçado sobre o verdadeiro estado do indivíduo, e só por meio de surpresas é que chegará a descobrir a verdade. Pode ainda a moléstia afetar um caráter intermitente; convém, portanto, que o indivíduo seja visitado mais de uma vez, por isso que, tendo ela esse tipo, se não pode ser reconhecida logo à primeira vez que se observa o sujeito; chegar-se-á a este fim visitando-o em diferentes épocas.

Além disso, muitas moléstias há capazes de simular a alienação, tais são a histeria, a epilepsia, a hipocondria etc. As febres de mau caráter deixam após de 
si um delírio crônico, que não se deve confundir com a alienação mental: as febres contínuas e intermitentes, atáxicas confundem-se com a loucura, principalmente em seu começo, por isso que ela apresenta muitas vezes quase todos os caracteres da febre atáxica. Convém, portanto, que o médico, para não se enganar, indague com toda a precisão e prudência os caracteres distintivos de cada uma delas. A embriaguez contínua pode também simular a loucura; todavia, abstração feita destes casos, o diagnóstico é geralmente fácil.

\section{Prognóstico}

O prognóstico deve ser feito segundo as causas, sintomas, complicações, duração da moléstia etc. Assim, coeteris paribus, as que não reconhecem por causa uma predisposição hereditária são menos graves; as provocadas por causas físicas o são também menos que as produzidas por uma causa moral: entre estas últimas, as afecções tristes e prolongadas são mais fatais que as emoções vivas e súbitas. A idade de 25 a 35 anos é a mais favorável para a cura: dos cinquenta em diante, é incerta. Curam-se mais mulheres do que homens, e a razão é clara: nas mulheres a alienação provém mais de causas físicas, no entanto, no homem influem mais as causas morais.

Quando na alienação mental há só perturbações das faculdades intelectuais, o prognóstico é mais favorável, e há mais esperança de cura do que se complica-se com a lesão dos órgãos dos sentidos; será ainda mais funesto se também houver complicação dos movimentos, porque, afinal, manifesta-se a paralisia, que é sempre incurável. Em cada uma das duas primeiras classes, isto é, quando há só perturbação das faculdades intelectuais, ou destas complicadas com a dos órgãos dos sentidos, a mania cura-se mais vezes que a monomania, e esta mais que a demência. Se a demência é aguda, a cura está na mesma relação que a monomania a respeito da mania. O idiotismo é sempre incurável. Se o indivíduo é bem constituído e forte, oferece mais esperanças de uma terminação feliz, do que se é linfático e há complicação de alguma moléstia crônica. $\mathrm{O}$ que tiver uma conformação regular do crânio será tanto mais suscetível de cura, quanto o será menos o que estiver em condição oposta.

A loucura intermitente, sobretudo se tem havido repetidos acessos, é mais difícil de curar que a contínua. Se moléstias do coração se complicam com a alienação, o prognóstico é sempre funesto. Finalmente, quando o alienado emagrece durante o período de intensidade do delírio, é um bom sinal; no caso contrário, a probabilidade de cura é menor: todavia, a gordura algumas vezes coincide com a volta da razão. Logo que os sintomas febris desaparecem, e a funções orgânicas 
começam a restabelecer-se, sem melhoramento da inteligência; isso anuncia a passagem da moléstia aguda ao estado crônico e, neste caso, quase sempre é incurável. Em suma, o tratamento aplicado a tempo e convenientemente, concorre muito para os bons resultados da cura, por isso que, a nosso ver, nada agrava mais as moléstias mentais do que a demora no tratamento adequadamente empregado.

\section{Anatomia patológica}

Temos, enfim, chegado à parte mais importante da nosografia médica. À proporção que a anatomia patológica faz progressos, vão se depositando nas mãos do médico mais dados para o verdadeiro conhecimento das moléstias e, por consequência, meios para administrar-lhes um tratamento certo e seguro; e na verdade, se a medicina é suscetível de uma demonstração matemática, a nada com mais justo título se deve dar este nome, que às demonstrações anatômico-patológicas.

Poucas moléstias têm excitado mais que a alienação mental, a curiosidade e zelo dos médicos e dos filósofos, para descobrir as causas dela no cérebro. Entretanto, as indagações multiplicadas feitas em todos os tempos pouco tem adiantado, que satisfaça, sobre as alterações mórbidas do cérebro dos alienados.

$\mathrm{Na}$ falta de observações nossas sobre as lesões patológicas encontradas nos cadáveres dos alienados, referiremos em resumo as observadas por Foville, Delaye e Georget, porquanto são estes, a nosso ver, os autores que melhores detalhes têm dado em seus trabalhos a este respeito.

Foville diz que as alterações observadas no cérebro dos alienados são de muitas espécies, afetam diferentes sedes, e não são as mesmas, segundo o estado de simplicidade ou de complicação da moléstia. Estas considerações, diz este autor, podem explicar a diferença dos resultados obtidos por autores que têm tido poucas ocasiões de repetir suas indagações.

Morgagni notou o endurecimento do cérebro, sua moleza, derramamentos serosos nos ventrículos ou nos tecidos da pia-máter, a aderência das membranas à superfície do órgão, o amolecimento da abóbada dos três pilares, a injeção das meninges e dos plexos coroides. Greding encontrou a espessura parcial em geral do crânio, o fétido e a moleza do cérebro, a atrofia das câmaras ópticas, a abundância ou ausência de serosidade nos ventrículos, o abatimento dos tubérculos quadrigêmeos, a presença de concreções ósseas no cerebelo. Haslam observou a aderência sólida ou laxa do pericrânio e da dura-máter aos ossos do crânio, a espessura destes ossos, o estado oposto; a dureza ou moleza do cérebro, coleções serosas nos ventrículos ou nas meninges. 
Esquirol notou, entre numerosas aberturas de corpos, crânios espessos ou adelgaçados, compactos ou ebúrneos, injetados ou exangues, um avultado número de crânios irregulares, a espessura e injeção de meninges, a ossificação das artérias basilares; cérebros densos ou moles, quistos serosos nos plexos coroides. Nenhuma destas alterações lhe parece constante: este autor diz que de todas as alterações que ele observou, nenhuma em particular tem relação à produção do delírio dos alienados, por isso que têm sido também encontradas em casos estranhos à alienação. Muitos outros médicos rejeitam inteiramente os resultados da anatomia patológica aplicada à alienação mental: um de seus maiores argumentos é que, sendo este resultado diferente segundo os indivíduos, nada se pode, por consequência, concluir de positivo.

Foville diz que, para apreciar com a maior exatidão possível as mudanças sobrevindas no cérebro dos alienados, examinou comparativamente os cérebros de indivíduos mortos sem desarranjo das funções intelectuais. Vamos passar, em resumo, às principais e mais constantes alterações observadas por Foville nos alienados à sua disposição, durante o espaço de três anos no hospital do Seine-Inférieure, e antes deste tempo no da Salpêtrière, encarregado aos cuidados de Esquirol.

As alterações cefálicas mais notáveis, observadas por Foville, são as seguintes: os ossos do crânio algumas vezes espessos, outras sem díploe, densos e ebúrneos, outras esponjosos e adelgaçados; desigualdade na forma da cavidade craniana; injeção, espessura, infiltração serosa da pia-máter; separação e adelgaçamento das circunvoluções cerebrais; a superfície do cérebro amolecida e aderente (principalmente no estado crônico) à pia-máter, de maneira que ela traz consigo parcelas da massa encefálica, quando se a desprende; injeção da substância cerebral, cor rubra da cinzenta. Separando-se as camadas assaz delgadas para não descobrir a substância branca, nota-se então essa cor vermelha mais ou menos carregada, oferecendo o aspecto de manchas marmóreas; pequenos pontos em forma de salpicos de sangue encontram-se muitas vezes no meio dessas manchas; a substância branca apresenta também as mesmas manchas, mas de uma cor violácea; e algumas vezes é também a sede de injeções sanguíneas; ordinariamente há aumento de consistência de uma e outra substância; o cérebro apresenta uma moleza e descoramento geral; a substância cinzenta torna-se de uma cor amarelada, e a branca de um branco sujo; nos ventrículos encontram-se coleções serosas, principalmente nos laterais. As outras alterações são muito menos comuns: a protuberância anular, e os quatro grossos troncos nervosos que dali partem; a medula alongada e a espinhal são raramente lesadas de uma maneira apreciável. Todavia, Foville diz ter achado muitas vezes os nervos olfativos duros e coriáceos, e ao mesmo tempo tão transparentes como a gelatina: ele encontrou quase as mesmas lesões nos nervos ópticos. É inútil dizer que estas lesões se encontram quando há complicação dos erros dos sentidos. O cerebelo apresenta as mesmas alterações, porém são mais raras. São estas as 
lesões mais notáveis que se têm encontrado no cérebro dos alienados; elas variam nos diferentes indivíduos. Segundo Foville, as da substância cinzenta são as mais constantes, pois que é ela, segundo diz esse autor, a que preside as funções da inteligência: outras vezes, porém, nenhuma lesão apreciável à anatomia patológica se demonstra no cérebro, nem em suas membranas.

Os outros órgãos, tais como os pulmões, coração, estômago, intestinos, e nas mulheres o útero etc., oferecem alterações de diferentes naturezas, relativas às moléstias de que os alienados eram afetados, ou seja, que essas moléstias se complicassem com a loucura, ou seja, que obrassem como causas dela. Mas, em suma, não poucas vezes esses órgãos, assim como o cérebro, nenhum caráter anatômico de inflamação apresentam.

\section{Sede e natureza da alienação mental}

Qual é a sede primitiva da alienação mental? Eis aí uma questão que ocupa há muito tempo o juízo e atenção dos médicos, e por ora nada ainda se tem resolvido de positivo. Cada um tem dado a sua opinião, querendo que ela prevaleça como certa. Passaremos a referir as opiniões dos que mais particularmente se têm ocupado deste objeto.

Alguns disseram que, sendo alienação uma moléstia da alma, era inútil e repugnante procurar sua causa na organização. Foville, combatendo com justiça essa opinião, diz que é, com efeito, despojar a alma dos seus mais nobres atributos, degradá-la a nivelar-se com a matéria, e supô-la suscetível de alteração. A alma, diz o mesmo autor, deve permanecer estranha a nossas indagações, mas, considerando-se o cérebro como o instrumento material de suas manifestações, e como o órgão da inteligência, nele é que se deve procurar a causa dos desarranjos sobrevindos em suas funções.

Os antigos, para explicar a produção desta moléstia, recorreram, como na nossa introdução fizemos sentir, a uma influência sobrenatural, ao poder de Deus, do demônio, dos gênios, dos espíritos, dos astros; à ação da bílis, da atrabiles, ou da pituíta sobre o cérebro; à efervescência dos espíritos animais, ou a seu movimento irregular; à presença no órgão do pensamento de materiais sutis, de vapores saídos do abdômen etc. Mas, graças ao progresso das luzes, hoje absurdos e puerilidades desta natureza não são recebidos senão com desprezo: não é tão de barato que se procuram dar razões de fatos observados no século presente.

Foderé diz que a loucura depende da alteração de um princípio da vida residindo principalmente no sangue. Gall e Spurzhein consideram que a loucura é o resultado de uma inflamação, a princípio aguda, e depois crônica, do encéfalo. 
Broussais crê que ela provém de um estado de irritação deste órgão. Desfour diz que a loucura depende de uma afecção dos plexos nervosos do baixo ventre, sem a participação do cérebro pelo menos primitivamente. Pinel diz que lhe parece, em geral, que a sede primitiva da alienação mental é na região do estômago e dos intestinos, e que desse centro se propaga, como por uma espécie de irradiação, a perturbação do entendimento; Prost dá a causa na afecção da mucosa gastrointestinal. Segundo Esquirol, a loucura tem muitas vezes a sua sede nos diversos focos da sensibilidade, colocados nas diferentes regiões do corpo, e não sempre no cérebro. Georget diz que a loucura tem sua sede primitiva no cérebro, e que ela é uma afecção idiopática deste órgão. Falret adota a opinião que acabamos de citar. J. Franck crê que esta moléstia não forma um gênero inteiramente distinto, mas outras afecções do cérebro, e diz que ela é muitas vezes o resultado da encefalite, da apoplexia, que se apresenta com a epilepsia, a paralisia etc., que, enfim, ela, como estas afecções, pode se apresentar com as diáteses inflamatória, gástrica, artrítica, raquítica e escrofulosa, carcinomatosa, nervosa etc. Delaye e Foville dão como sede primitiva da alienação mental, a substância cinzenta superficial do encéfalo. Tais são as diferentes opiniões dos autores sobre a sede primitiva desta moléstia: mas hoje não resta dúvida alguma que é uma afecção do cérebro, seja idiopática, sintomática ou simpática. Resolver, porém, qual seja a parte do cérebro primitivamente afetada, é o que ainda não se tem podido fazer. A opinião de Foville, de que é a substância cinzenta superficial do cérebro, parece ser mais razoável, porquanto não só é admitido por muitos fisiologistas que a substância cinzenta é a que preside as funções da inteligência, mas ainda a observação mostra que é ela a mais constantemente alterada: todavia, como isto não sucede sempre, guardamo-nos de dá-la como certa, e esperemos que indagações ulteriores descubram qual a sede primitiva das vesânias, que ainda hoje é desconhecida.

Quanto à sua natureza, estamos no mesmo caso, isto é, ainda ignora-se. Muitos caracteres anatômicos de inflamação, quer do cérebro, quer das meninges, acompanham a alienação mental, como fizemos ver, tratando da anatomia patológica, o que faz muitos autores pensarem que esta moléstia é de natureza inflamatória, e Foville é desta opinião. Mas outros fatos, observados mesmo por Foville, Georget e outros, em que o cérebro não tem oferecido vestígio algum de inflamação em sua substância ou em suas membranas, induzem a crer que tal não é a sua natureza. Disto se deverá concluir: primeiro, que se, em muitos casos, a loucura é o resultado de uma encefalite ou meningite crônica, em outros nada nos autoriza a considerá-la como de natureza inflamatória; segundo, que naqueles mesmos em que a moléstia é acompanhada de caracteres anatômicos de inflamação do cérebro e de suas membranas, como se não tem podido provar que essas lesões são especiais da alienação, por não se confundirem com nenhuma das outras produzidas pelas diferentes afecções do cérebro, não se poderá determinar se essas lesões orgânicas 
são causa da modificação desconhecida, da qual depende a loucura, ou se são um efeito dela; e tanto mais, que alguns desses mesmos autores que admitem a existência dessas lesões orgânicas são concordes em dizer que elas não são a causa das vesânias, mas sim o resultado de uma causa menos aparente ou desconhecida, que a produz. Eis tudo quanto se pode dizer de positivo, no estado atual da ciência, respeito à sede e natureza das moléstias mentais.

\section{Tratamento}

O tratamento da alienação mental, assim como o das outras moléstias, tem sofrido todas as vicissitudes das teorias médicas. Os antigos faziam-no consistir no uso do heléboro. Aqueles que consideravam como causa da loucura o transporte de sangue ao cérebro, usavam prodigamente das sangrias. Os humoristas, julgando a bílis e atrabílis fonte dos desarranjos intelectuais, lançaram mão exclusivamente dos evacuantes. Em suma, outros muitos meios empíricos, e que o acaso tornava úteis, foram postos em prática. Atualmente, os meios mais preconizados para o tratamento da alienação mental estão em descrédito, já por insuficientes, e já mesmo por prejudiciais. Acreditamos que eles não são tão insuficientes e prejudiciais como se quer inculcar, por isso que esses inconvenientes necessariamente devem aparecer todas as vezes que se lançar mão deles sem distinção, sem luzes e sem reserva, fazendo-se uma aplicação banal à massa dos alienados: mas, quando se faça uma aplicação racional, preenchendo-se as indicações que se apresentarem, muitas vezes serão coroados de felizes resultados.

Para curar a alienação mental, o médico põe em prática dois meios de tratamento: um consiste em obrar diretamente sobre o cérebro, isto é, modificar o órgão pelo exercício mesmo de suas funções; é este tratamento chamado intelectual ou moral; o outro obra indiretamente, e é fornecido pela terapêutica, é este o tratamento físico ou médico propriamente dito.

O bárbaro costume de castigar os doidos e carregá-los de cadeias, e que constituía, no pensar dos antigos, a parte mais proveitosa do tratamento desta moléstia, se acha proscrito nos países em que mais se tem adiantado o estado da alienação mental; é depois que Pinel elevou a voz a favor desses infelizes, que tão desumano modo de tratamento vai sendo abandonado, e hoje a experiência mostra que a doçura é mais poderosa que os ferros e azorrague. No hospital da Misericórdia, desgraçadamente, ainda segue-se este bárbaro modo de tratamento; talvez que não faltássemos à verdade se disséssemos ser este, quase exclusivamente, o que ali enfermeiros ignorantes empregam nos alienados, frustrando quiçá as determinações dos professores encarregados do seu tratamento. 
Não basta esses entes infelizes verem-se privados da sua razão, ainda mais era necessário serem ali lançados, como que degradados do resto da espécie humana, em uma casa onde (graças ao bom desempenho que os seus administradores dão aos regulamentos de sua instituição) não há algum regímen, limpeza, polícia e caridade, e cujo local oferece por sua posição topográfica todos os inconvenientes à esperança de sua cura. Invocamos o testemunho das pessoas que têm visitado aquela casa, e elas dirão se o nome de calabouço não the era mais apropriado.*

Perdoe-nos aquela expressão um pouco dura, mas a franqueza em um médico deve ser o seu primeiro característico: não será um amor próprio mal entendido em querer supor boas todas as coisas do nosso país, que nos fará fechar os olhos ao estado de abandono em que aqui se acham os alienados, e ao atraso em que está ainda o estudo desta importante moléstia. Nem com isso nós ofendemos, nem temos em menospreço a nossa pátria, porquanto somos o primeiro em reconhecer que, apesar de sua infância e dos tropeços que tem tido de lutar constantemente, mesmo depois que começou a desfrutar os gostosos frutos de sua emancipação política e liberdade, ela tem visto crescer em seu seio muitas instituições e melhoramentos, admirados mesmo pelas nações civilizadas da velha Europa. Mas todas as coisas não se podem levar a efeito em um só dia, e esperamos ver ainda que no Brasil (onde, para honra nossa, já se conta um grande número de práticos respeitáveis pelo seu saber e ilustração) se estabeleçam, debaixo dos auspícios médicos, hospitais que ofereçam todas as vantagens, tanto no local como na polícia, regímen e tratamento para a cura desta lamentável moléstia. Dizemos que se estabeleçam hospitais próprios, porque é sabido que se tiram vantagens tratando-se os alienados isoladamente, do que no seio de suas famílias.

Notemos os inconvenientes que se encontram no segundo modo. Um carinho mal entendido da parte dos parentes em condescender com suas vontades, ou antes com seus caprichos, são motivos poderosos que se opõem à sua cura: muitas vezes

*Quando escrevemos este artigo, a casa destinada para os doidos no hospital da Misericórdia merecia, sem hipérbole, o nome que lhe demos; mas, de então para cá, construiu-se uma outra, cuja vantagem consiste simplesmente em ser ela ainda nova, não ter tanta umidade e ter um quarto ou cela para cada insensato; porquanto, a mesma falta de ordem, regímen e polícia, de preceitos higiênicos, de distrações e ocupações continuam; assim como o uso, ou antes o abuso, do tronco, como meio de repressão; todavia, sirva-nos ao menos isso de esperanças que para o futuro seja sua sorte melhorada, e lisonjeemo-nos que, após do melhoramento de casa, venha vindo também o de tudo o mais. Lembraremos, entretanto, que quaisquer que sejam as modificações boas que possa vir a ter aquele estabelecimento de loucos, jamais ele poderá preencher o seus fins, porquanto só a circunstância do local em que se acha situado basta para que se desespere de que possa ser útil aos doidos. (Nota do Autor) 
esta condescendência chega a tal ponto, que obedecem cegamente as suas ordens: a consequência que daí resulta, é que o doente, obtendo uma satisfação plena, e a cada instante repetida, de suas vontades, adquire, por este exercício constante, uma força desmedida em suas faculdades já muito enérgicas, e se fortifica ainda mais da ideia de que todos o obedecem: além disso, suponha-se que há um pai de família, e que não se quer obedecer a seus caprichos: como poderá ele sofrer a sangue frio ser desobedecido por pessoas que lhe tributavam anteriormente respeito? Muitas vezes a causa da moléstia existe no seio da família, ela tira a sua origem das dissensões e desgostos domésticos, e por isso, a presença dos parentes e amigos, estando em relação com as causas que a provocaram, irritam o mal e entretêm o delírio por mais tempo. Outro inconveniente ainda se apresenta, e é que muitas vezes os amigos e parentes do alienado, que tinham mais influência ou autoridade sobre ele, procuram, por meio de argumentos, convencê-lo do seu delírio e dos seus erros; isso, que eles fazem na persuasão de ser-lhe útil só serve para excitar, em cada discussão nova, esforços intelectuais incríveis para achar razões com que motive sua conduta e seus discursos, o que afinal acaba por exaltar e confundir suas ideias, tornando-se deste modo a cura muito mais difícil. Finalmente, os receios e medo, que agitam constantemente as famílias em cuja casa existe um alienado, os desgostos que elas sofrem, tendo os olhos constantemente em um de seus membros afetado desta triste moléstia; e em suma, os prejuízos e grandes despesas em que incorre quem tem de tratar um alienado em casa, são outros tantos inconvenientes que se apresentam; no entanto, que são favoráveis ao isolamento. Vejamos as vantagens deste.

Isolados de tudo quanto os cercava anteriormente, vendo novos objetos, podem, com mais facilidade, concentrar-se em si mesmos, e esquecer-se do seu delírio com a aquisição de novas ideias. A vista de seus companheiros na desdita pode ser-lhes muito proveitosa, por isso que, nos momentos em que eles se acharem menos agitados, podem refletir nas extravagâncias dos seus companheiros, e daí tirar meios proveitosos para curar-se de seus erros. Sobre este ponto, alguns autores insistem ainda contra o isolamento; dizem eles que, muito pelo contrário, os doidos sendo tratados em uma só casa é muito prejudicial, não só porque eles têm de chocar-se constantemente, como porque os erros e delírios de uns arraigam mais os dos outros, o que se opõe à sua cura. Mas outros muitos, e entre eles Esquirol, a quem não se pode negar muitos conhecimentos e prática na cura desta moléstia, diz que tem colhido vantagem com este sistema. Como o que se quer são fatos, e não teorias, inclinamo-nos à opinião do excelente prático que acabamos de citar. Nota-se que os alienados, em geral, tomam aversão aos parentes e amigos a quem tinham mais afeto, no entanto que os estranhos lhes são mais agradáveis, e é esta mais uma razão a favor do isolamento. Finalmente, o desejo de verem-se livres, a necessidade de estarem com os parentes e amigos, pela mesma razão de acharem-se privados deles, são muitas vezes motivos poderosos que os forçam a esquecer-se 
do seu delírio, ocupando-se daquelas ideias. Todavia, casos há em que o isolamento (assim como todas as causas as mais úteis) pode ser danoso aos alienados; não se deve, portanto, ser absoluto na prática. A arte consiste em bem prever as circunstâncias que podem ou devem modificar os princípios, qualquer que seja a força que a experiência lhes dá.

A construção e direção de uma casa de alienados influi muito para o bom êxito do tratamento. Um tal estabelecimento deve ser feito fora das grandes povoações e cidades, em um lugar plano e elevado, e disposto de modo que o ar possa renovar-se facilmente. Deve oferecer separações distintas e suficientes para que os doentes turbulentos e furiosos estejam separados dos tranquilos: os que se acham em tratamento, dos incuráveis; os convalescentes, de todos os outros; e finalmente, os epiléticos, ou os que padecem de alguma outra moléstia acidental, que possa ser danosa aos outros, devem ser separados deles cuidadosamente, e por isso, além desta divisão principal, será útil ter quartos distintos para os doentes que já não sentem suas necessidades. Deve-se também isolar os doentes que, sendo de costumes depravados, praticam atos ilícitos. Cada divisão deve ter um pátio plantado de árvores, ou mesmo um jardim para servir de recreio e distração aos loucos. Não se pense que nós estamos aqui fazendo descrições romanescas. Todos os autores concordam com a necessidade desses meios de distração para o bom sucesso da cura destes desafortunados doentes, e parece que ninguém negará a sua utilidade. O mui digno prático, o Sr. Dr. Cardozo, quando estabeleceu nesta Corte um hospital particular, também recebia doentes afetados da loucura, e este prático tinha um jardim bem plantado que servia de recreio aos alienados, do que colhia vantagens. É para lastimar que o Sr. Dr. Cardozo se visse na impossibilidade de continuar a manter o seu estabelecimento, que alguns bens prometia, talvez por não encontrar outros companheiros que com ele quisessem encarregar-se de uma tão árdua tarefa, qual é a da direção de um hospital.

É absolutamente indispensável que um regulamento sabiamente combinado sirva de regra comum nas casas de doidos; e o médico deve aí ser investido de um poder superior em tudo o que respeita o serviço particular dos doentes. Uma vigilância ativa sobre eles é muito necessária: os que têm inclinação ao suicídio não se devem perder de vista um só momento, assim como os turbulentos, e os que se dão ao onanismo; convém usar com eles dos meios de repressão, e por isso devem ser contidos pela camisola de força, sofrer algumas privações, e mesmo ser intimidados e ameaçados de castigos, mas nunca com alguma espécie de injúria, ou de mau tratamento. Eles olham sempre o diretor e os enfermeiros do estabelecimento como cúmplices da autoridade que lhes roubou a sua liberdade; e por isso serão sempre o objeto de sua prevenção, suspeitas e ódio; é preciso, portanto, que se sofram de algum modo os seus ataques e injúrias; e, além disso, não se deve atribuir à maldade o que só é efeito da moléstia. Alguns enfermeiros há tão bárbaros e ignorantes, que 
não relevam a menor falta nesses entes infelizes; poucos há que não digam que os alienados gozam da maior parte das suas faculdades, a menos que já tenham também sofrido da mesma moléstia. Tal é, de uma maneira geral, o modo por que se deve regular uma casa de doidos: é impossível poder-se especificar e prevenir tudo: o resto está na sagacidade do médico; a ele toca obrar, segundo as circunstâncias, de modo que as coisas se façam com ordem e utilidade.

No tratamento moral, reduzem-se a três princípios todas as modificações que convém fazer aparecer no exercício da inteligência dos insensatos: 1) não excitar as ideias ou paixões dos doentes no sentido do seu delírio; 2) não combater diretamente suas ideias e opiniões errôneas, pelo raciocínio, contradição, gracejo ou gritaria; 3) procurar fixar sua atenção sobre objetos estranhos ao delírio, e comunicar a seu espírito ideias e afetos novos por impressões diversas. Pelo primeiro princípio evitam-se as causas que provocaram a loucura, e mesmo a lembrança de objetos que estão em relação com elas: v. g., os alienados atacados de monomania religiosa serão privados de seus livros de devoção; aqueles cuja mania é dizerem que são deuses, reis etc., não devem ser lisonjeados em suas preocupações e ilusões; assim todos os mais casos. Pelo segundo princípio, evita-se argumentar com os alienados para conduzi-los ao bom senso, porquanto tendo eles convicção de que não estão em erro, as provas mais evidentes nada podem sobre seu espírito; e estas discussões só servem de irritar mais o doente, fortificar seu delírio excitando o órgão afetado, e inspirar-lhe mais desconfiança e furor. Pelo terceiro, procura-se distrair seu espírito por diferentes meios, tais como o exercício e trabalho, leituras, conversações etc. É por isso que muito convém empregar os alienados em diferentes ofícios e ocupações. Alguns autores dizem que as comoções morais vivas e repentinas são úteis para a cura dos alienados. Não duvidamos que em um ou outro caso este meio seja proveitoso, mas, em geral, servirá antes para agravar o mal. Também citam-se alguns fatos que fazem exceção aos princípios que acabamos de estabelecer; e assim alguns autores dizem que em certos casos é conveniente o médico aplaudir as extravagâncias do doente: v. g., se o delírio consiste em estar persuadido que tem um animal no ventre, administra-se-lhe um purgante, e põe-se com cautela um bicho entre o excremento, e isso muitas vezes basta para fazer cessar o delírio. Esquirol refere o caso de uma menina alienada, que dizia ter um bicho na cabeça: diz o autor que concordara nesta ideia com a doente, e lhe propusera uma operação, à qual se submeteu: ele incisou levemente a pele do crânio e mostrou à doente um inseto de que de antemão se munira; e isso bastou para a sua razão se restabelecer. Como quer que seja, os exemplos deste gênero são extremamente raros: de ordinário, os estratagemas postos em prática não produzem resultado algum feliz, ou seja porque os doentes têm bastante perspicácia para conhecer o engano, ou seja porque, vendo eles que há meios de satisfazer aos seus caprichos, substituem a ilusão destruída por outra nova. Temos estabelecido os princípios em que o médico se deve firmar para 
o tratamento moral dos alienados; está na sua habilidade usar deles, modificando-os conforme a índole, inclinações e natureza do delírio do doente. São necessárias ao médico lembranças e sutilezas de todos os momentos; é preciso ganhar a confiança do doente, ouvir com paciência e caridade suas queixas, e seus desarrazoados; deve persuadi-lo de que se interessa pelo estado: tudo isso é indispensável para poder colher frutos proveitosos de suas fadigas.

Uma parte importante do tratamento moral consiste em prevenir as recaídas, ou seja durante a convalescença, ou seja depois da cura, quando os doentes são novamente restituídos à sociedade. Eles logo se curam, recordam-se da posição em que se acharam, das causas que os privaram da razão, das inquietações e desgostos que causaram a suas famílias, da perda da sua fortuna etc. Além disso, a maior parte deles tornam-se muito suscetíveis e irritáveis. Que considerações morais não convêm empregar para distraí-los das ideias tristes e aflitivas que os consomem, e cuja permanência pode acabar por aliená-los de novo! Mas são casos estes para o que não se pode estabelecer princípios certos e invariáveis: é mister obrar conforme as circunstâncias peculiares que concorrem em cada alienado.

Os meios higiênicos a empregar na cura dos alienados são relativos ao regímen, vestuário, cuidados da limpeza e aos exercícios.

Os alimentos devem ser de fácil digestão e distribuídos com discernimento; a dieta é quase sempre impraticável, e mesmo raramente útil, porque a cólera e o furor que seguem uma recusa de alimentos fazem mais mal do que a privação pode fazer bem, e por isso ela só é praticável nos primeiros dias da moléstia. Alguns doentes recusam comer por motivos que suas ideias errôneas lhes sugerem; em tal caso, convém obrigá-los a tomar alimentos, usando para este fim de certas privações. Muitos são devorados pela sede; é preciso satisfazer estas necessidades por bebidas apropriadas: os alimentos e bebidas excitantes, em geral, são-lhes nocivos; todavia, em alguns casos de demência e melancolia, assim como na convalescença, elas são indicadas.

As secreções e excreções devem ser favorecidas por todos os meios possíveis, é mister, portanto, ter cuidado em conservar o desembaraço do ventre; sabe-se que a constipação é um sintoma mui frequente, e que fatiga os doentes, se não entretém a moléstia.

Os vestidos devem ser quentes, sobretudo nos melancólicos, nos quais tudo o que serve a restabelecer a transpiração é útil. Muitos creem que é conveniente privar os alienados do calor, e que eles se acham bem em uma habitação fria, mas isto é um grande erro, a não se ter conta a casos mui raros. A disposição em contrair o escorbuto prova quanta necessidade eles têm de uma habitação seca, e onde o ar transite livremente.

Os exercícios do corpo devem ser também postos em prática: eles não só servem a distrair o delírio dos alienados, mas ainda a favorecer a transpiração, que 
tantas vezes concorre para sua cura. É mister, portanto, que sejam empregados em trabalhos proporcionados à sua posição.

Os cuidados da limpeza consistem particularmente: primeiro, em trazer sempre lavadas as salas e quartos dos alienados imundos, assim como as enfermarias; segundo, em renovar os lençóis das camas, e as roupas sujas pelos excrementos dos doentes; terceiro, em lavá-los e trazer vestidos de modo mais compatível com o seu estado.

Alguns autores dizem que a música pode produzir efeitos saudáveis sobre os alienados, mas ela deve ser empregada conforme as inclinações do doente, por isso que se pode servir de cura a alguns loucos, não é menos certo que a outros agrava o mal. Esquirol diz não ter colhido vantagens com o seu emprego.

Os espetáculos têm sido também preconizados para a cura desta moléstia; todavia, autores modernos têm se declarado contra este meio. Esquirol diz não ter tirado dele proveito algum; ao contrário, afirma que, levando alguns de seus convalescentes à ópera, notou que a moléstia se agravava. Os meios de distração são, sem dúvida, os mais eficazes para curar esta enfermidade; mas não se deve contar com o sucesso dos que exaltam a imaginação e as paixões, pelo que os espetáculos, em geral, não podem convir aos alienados.

A mudança de clima é muito proveitosa, principalmente nas alienações intermitentes, e naquelas cuja causa é moral; por isso, as viagens são de muita utilidade no tratamento das moléstias mentais; elas não só oferecem objetos de distração aos doentes, mais ainda, deixando eles de estar em contato com a causa que produzira a loucura, podem com mais facilidade recobrar a razão, muito principalmente fazendo a aquisição de ideias novas com a presença de novos objetos; além disso, se o mesmo clima é a causa da loucura, o indivíduo, mudando-se do lugar em que se acha, há probabilidade de que possa curar-se; esta verdade é tão confirmada pela experiência, que Esquirol diz que no hospital da Salpêtrière, curavam-se mais alienados vindos das províncias e de países estrangeiros, do que os que já habitavam em Paris antes de alienar.

A parte da terapêutica, que tem por objeto a administração de remédios propriamente ditos, ou o tratamento chamado físico ou médico, não se baseia sempre sobre princípios bem fixos; muitas vezes, as indicações a preencher são difíceis de conhecer-se, e pouco ou nada determinadas; a natureza mesmo da moléstia está mui longe de ser sempre apreciada; por isso, para firmar a base de uma terapêutica segura no tratamento da alienação mental, seria preciso conhecer todas as causas gerais ou individuais desta moléstia, e outras muitas circunstâncias que podem influir para que ela tome um caráter particular. Convém distinguir o foco de onde partem todas as desordens, determinar se é o físico que reage sobre o moral, ou se este sobre aquele. Umas vezes a loucura é idiopática, outras sintomáticas, outras é o resultado da supressão de um corrimento qualquer, ou de sarnas, 
dartros etc; ora, dadas todas estas diferenças, claro fica que se não pode estabelecer um modo de tratamento invariável para esta moléstia; ao médico pertence ir preenchendo as indicações que se forem apresentando, segundo as diversas complicações.

Quando se tem combatido e superado as disposições gerais e os funestos efeitos de causas particulares, se a moléstia não se cura, então se usará de um tratamento especial; mesmo assim, é preciso variar continuamente os meios que se têm de pôr em prática. Alguns médicos têm aconselhado a medicina expectante, sobretudo nos casos em que indicação alguma se apresenta; todavia, este método nem sempre é razoável, pode-se muitas vezes abandonar o organismo às suas próprias forças, contando com uma marcha natural da moléstia, e em resultado ter uma terminação funesta. Seguindo-se esta prática, pode acontecer que um acesso de mania, por exemplo, ou de melancolia aguda, que cederia prontamente a um tratamento ativo, degenera em um estado de demência incurável. Não dissimularemos, entretanto, que no estado atual da ciência, o médico encontra muitas vezes casos de alienação sem indicações terapêuticas bem precisas, que o levam ou a nada fazer, ou a lançar mão às apalpadelas de alguns meios reputados como especiais desta moléstia. Vamos falar dos medicamentos mais empregados no seu tratamento, e no fim apresentaremos um resumo do que o Sr. Dr. de Simoni, médico da enfermaria dos alienados do hospital da Misericórdia desta Corte, tem posto em prática com mais vantagens.

As sangrias têm sido reprovadas por alguns médicos. Pinel as julga prejudiciais no maior número de casos. Esquirol, não se exprimindo do mesmo modo sobre os perigos das sangrias, não olha, todavia, este meio como geralmente útil. Este médico diz que viu a loucura aumentar depois de regras abundantes, e de uma, duas ou mais sangrias. Entretanto, esse autor não proscreve o emprego desse meio, julga-o mesmo indispensável aos alienados pletóricos, e ameaçados de congestões cerebrais, e quando há supressão de alguma evacuação sanguínea habitual etc. Acreditamos que as emissões sanguíneas têm sido proscritas com muita severidade; este meio é útil e mesmo necessário nos doentes fortes e pletóricos, quando a moléstia é recente, e em casos de supressões sanguíneas, de congestões etc.; todavia, para evitar os inconvenientes que se lhe notam, mister é ter em vista certas considerações: primeira, nos casos de excitação e congestão cerebral, as emissões sanguíneas devem se combinar com aplicações refrigerantes sobre a cabeça e com a ação de agentes revulsivos; segunda, devem se preferir as sangrias locais às gerais, não só a sua ação é mais direta, mas ainda não produzem perdas sanguíneas inúteis; terceira, as sangrias locais, feitas com prudência, oferecem a vantagem de poder ser repetidas por muitas vezes sem inconvenientes, mesmo nos indivíduos fracos.

A água tem sido empregada de todos os modos, já em banhos tépidos, frios e semibanhos, já em pedilúvios, em embrocações, bebidas e clisteres. Os banhos frios ou apenas tépidos são úteis nos alienados fortes, e que sentem muito calor. Os de surpresa e imersão, tão preconizados pelos antigos, hoje estão proscritos; se 
o acaso os tem feito curar um ou outro, em geral podem ser de funestas consequências; os tépidos são os que mais geralmente se empregam, assim como os semibanhos, os quais obram como revulsivos. As embrocações, tão gabadas por alguns autores, nem por isso oferecem sempre os bons resultados que se inculcam do seu uso. Como refrigerantes, poderiam ser úteis, se fosse possível durar sua ação por muito tempo, isto é, se um desenvolvimento considerável de calor não substituísse logo os efeitos do frio: debaixo deste ponto de vista, as aplicações frias prolongadas sobre a cabeça são muito mais vantajosas. Todavia, como meio moral, as embrocações são proveitosas para reprimir os doentes, obrigá-los ao trabalho e exercício, ou, enfim, para excitar comoções morais. Em geral, os alienados têm muita sede, é mister não os privar dos meios de a saciar. Alguns autores aconselham o uso da água bebida abundantemente para combater a inclinação ao suicídio; parece-nos que este meio só não poderia bastar para curar esta tão danosa inclinação. Os clisteres simples ou compostos são úteis nesta moléstia, tão frequentemente acompanhada de constipação.

Os evacuantes, tão falados desde os tempos mais remotos para o tratamento da loucura, nem sempre são úteis. Os autores modernos aconselham os vomitivos; eles convêm em algumas melancolias com estupor, e aos indivíduos cuja sensibilidade se acha embotada e que parecem atacados de atonia; mas deve-se evitar o seu uso quando há pletora cerebral. Os purgativos são aconselhados no maior número de casos por todos os médicos; a sua escolha, porém, não é indiferente; deve-se preferir umas vezes os drásticos, outras os vermífugos, e outras os ecopróticos; em suma, o seu emprego deve ser modificado conforme as condições individuais. Os mais comumente empregados são o heléboro, a goma guta, a briônia, o aloés, o muriato de mercúrio, o tartarato antimoniado de potassa e as águas minerais purgativas: está na perícia do médico lançar mão deles segundo as circunstâncias. Em algumas ocasiões, os purgativos oferecem seus inconvenientes; eles podem causar irritações e suspender a atividade da pele: previnem-se estes acidentes alternando-os com os tônicos e banhos tépidos.

A cânfora, digitális, quina, o musgo, o ferro, antimônio e o mercúrio têm sido propostos como específicos para combater a loucura. Estes medicamentos são úteis, mas sua utilidade é individual; os seus efeitos podem ser benéficos, quando seja indicado o seu emprego, mas aplicá-los a todos os alienados seria prejudicial.

$\mathrm{O}$ ópio tem sido aconselhado como um remédio heroico por alguns autores de crédito; todavia, Esquirol assegura que os narcóticos são mais nocivos que úteis, muito principalmente se há pletora sanguínea e congestão para a cabeça. Se o ópio administra-se aos alienados para obstar a insônia que eles sofrem, em tal caso é mais prudente empregar o regímen, trabalho e exercícios que não acarretam perigo algum, do que fazer uso de um medicamento que a prática diária confirma ser prejudicial aos alienados. 
Os sedenhos, moxas, cautério atual, vesicatórios, ventosas e fricções irritantes, têm sido empregados: o seu uso deve estar em relação com as circunstâncias individuais. $\mathrm{O}$ vesicatório, ventosas e as aplicações irritantes são proveitosos quando há uma metástase; na loucura, em consequência de partos; e na demência quando não há complicação de paralisia ou convulsões. Tem-se proposto envolver a cabeça de emplastros epispásticos, e outras composições irritantes: deve-se convir que estes meios não são sempre proveitosos, pois que aumentam o eretismo, atormentam os doentes, irrita-os, e os fazem persuadir que isso se pratica por suplício. Contudo, quando outros tenham falhado, e este seja indicado, é mister usar dele, porque é em benefício do doente, apesar de ele crer o contrário: nas manias crônicas, v. g., em alguns casos de demência, nos quais se prescrevem uma medicação ativa e perturbadora, eles podem ser úteis. O fogo e as moxas têm sido também aplicados com proveito, conforme asseguram alguns práticos, no vértice da cabeça, no ócciput e na nuca, em casos de mania; Esquirol diz não ter obtido efeitos saudáveis do seu emprego: pensamos que ele pode ser proveitoso na demência crônica, quando é complicada com paralisia, mas que ainda não está muito adiantada.

Muitos práticos, entre eles Gmelin e Perfect, dizem ter curado a loucura pela eletricidade, outros têm experimentado o galvanismo e magnetismo, e dizem ter tirado vantagem. Esquirol assegura que tentara esses meios sem proveito. Pensamos que os choques elétricos em alguns casos podem ser úteis, principalmente nos indivíduos minimamente nervosos, nos histéricos etc.

Para terminarmos o que temos a dizer sobre o tratamento físico da alienação mental, resta-nos notar que algumas indicações curativas podem ser deduzidas de uma maneira mais precisa da causa da moléstia, sua natureza, marcha e complicações. Muitas vezes, segundo dissemos, a loucura se desenvolve lentamente; não há dúvida que se o médico fosse chamado a tempo e conhecesse a causa e natureza do mal, obteria um pleno sucesso, ou subtraindo o doente à ação da causa, ou combatendo os primeiros acidentes. A insônia, dores de cabeça, certas mudanças no caráter de um indivíduo etc. devem ordinariamente fazer desconfiar alguma moléstia grave do cérebro; se nesta época fizessem-se cessar as causas, usando-se de meios de distração, de banhos tépidos, dos derivativos ao canal intestinal ou à pele, se se empregassem as emissões sanguíneas, seriam esses meios preventivos suficientes para obstar as consequências mais graves. Os corrimentos e exantemas suprimidos devem ser restabelecidos, ou, pelo menos, substituídos por outros. Um estado de pletora geral se apresenta em muitos alienados, ou no começo ou no curso da moléstia; sabem-se quais são os sintomas que caracterizam um tal estado, e os meios que se lhe opõem são conhecidos: se não lança-se mão das emissões sanguíneas e outros debilitantes, os doentes podem sucumbir a uma congestão. Outro estado oposto ao precedente, isto é, uma espécie de anemia, nota-se em alguns doentes, ou porque tinham sido sangrados demasiadamente, ou porque este 
acidente existe em alguns infelizes que se tornam alienados depois de ter caído na mais profunda miséria, ou, em suma, porque eles se obstinam a não tomar alimentos de natureza alguma: neste caso, um regime tônico sem ser muito excitante, o ar do campo, os exercícios moderados reanimarão pouco a pouco suas forças, e podem restituí-los à razão. Em muitos casos existe um estado agudo de irritação no cérebro: o tratamento deve então constar de depleções sanguíneas, banhos tépidos, aplicações frias sobre a cabeça, refrigerantes, pedilúvios sinapisados, e bebidas laxativas, se o canal intestinal se acha em bom estado.

Há alienados cujas funções nutritivas estão em perfeito estado, a circulação e o calor se acham no estado normal; em suma, não sofrem coisa alguma: deliram, e eis todo o seu mal aparente! Qual é nestes doentes a natureza da afecção cerebral, e que indicações se tem a preencher?! Neste caso, convém seguir a medicina expectante, o médico deve esperar tudo do tempo, que é o verdadeiro modificador das coisas; empregar sobre o alienado comoções morais, porque só estas é que diretamente podem modificar o mesmo moral afetado.

O Sr. Dr. de Simoni comunicou-nos que as circunstâncias do local da casa de doidos no hospital da Misericórdia desta Corte não oferecem os cômodos necessários, antes são as mais contrárias ao tratamento, quer moral, quer físico; todavia, que elas são menos adversas a este do que àquele, que quase de nenhum modo pode aplicar-se.

O tratamento físico geralmente empregado pelo Sr. Dr. de Simoni é o antiflogístico direto e indireto. Consiste este nas sangrias gerais do pé e do braço; locais do ânus, períneo, epigástrio, nuca e apófises mastoides, por bichas ou ventosas, associadas ao uso repetido e prolongado de laxantes ecopróticos e às vezes catárticos; revulsivos, epispásticos às extremidades inferiores e à nuca. Mui poucos são os casos em que emprega os cáusticos, a não ser o estado crônico. Este tratamento só pratica no princípio da moléstia, enquanto apresenta sinais de agudeza e estado flogístico notável; apenas o enfermo oferece melhoras consideráveis na gravidade dos sintomas; o Sr. Dr. de Simoni diz que usa de um método expectante, tendo conhecido pela experiência que o tempo é o melhor modificador das vesânias, e que ele por si só cura muitas sem auxílio da terapêutica. Quando o delírio se exacerba pelo tratamento antiflogístico, não insiste nele; em muitos casos usa das embrocações de água fria e dos banhos de mar com sucesso. A beladona, o meimendro, heléboro e todos os outros remédios farmacêuticos gabados como específicos para esta moléstia, nenhum efeito feliz têm-lhe dado. O mesmo senhor disse-nos que raras vezes lhes aparece e fala quando estão em furor, e principalmente estando eles com ilusões, e em estado de o não conhecer. A camisola de força, prisões em quarto fechado, a do pé no tronco para os que as duas primeiras não podem conter, algumas vezes a diminuição da comida são os meios repressivos de que pode fazer uso. Quanto ao moral, o Sr. Dr. de Simoni diz que procura conversar com eles, 
interrompê-los com perguntas destacadas e alheias do objeto de seu delírio: quando eles se queixam do estado de violência em que se acham, procura sempre fazer-lhes crer que pratica isto obrigado por uma autoridade superior, com a qual luta para beneficiá-los e fazer-lhes as vontades. Ele nos disse que com este método, apesar de mesquinho e forçosamente imperfeito, muitos se têm curado.

As recaídas são frequentes pela repetição das causas determinantes, principalmente nos que usam de bebidas alcoólicas, os quais, se não acabam hidrópicos, morrem epiléticos ou apopléticos.

Não podemos concordar com o meio de repressão adotado pelo Sr. Dr. de Simoni em fazer meter os doidos no tronco: além de importar isso a exasperá-los mais, tem ainda o inconveniente de fazê-los perder o estímulo; nem se diga que eles não estão em estado de poder avaliar os atos de degradação que com eles se pratica, porque apesar do desarranjo de suas faculdades intelectuais, eles têm a consciência de si e do que os cerca. Sabemos que é talvez a lei da necessidade que leva o Sr. Dr. de Simoni a usar de semelhante meio, por isso que o estabelecimento não oferece proporções alguma para pôr em prática outras mais dóceis e racionais*: foram estas considerações que nos levaram a fazer algumas reflexões a este respeito em outro lugar. Esperemos que o tempo depare uma melhor sorte aos doidos no nosso país!

Temos, enfim, tocado o termo da nossa tarefa; não dissimularemos quanto mal a desempenhamos, atendendo a insuficiência de nossos conhecimentos e capacidade, mas, ao menos, satisfizemos ao que sinceramente almejávamos, isto é, lembrar a matéria e sua utilidade, para ser melhor desenvolvida e tratada por gênios mais sublimes e felizes que o nosso.

FIM

* Os comentários do Dr. Luiz Vicente de Simoni sobre o uso do tronco, respondendo às críticas de Peixoto, podem ser lidos em artigo publicado na Revista Médica Fluminense em setembro de 1839. 'Importância e necessidade da criação de um manicômio ou estabelecimento especial para o tratamento dos alienados' foi republicado na Revista Latinoamericana de Psicopatologia Fundamental, 7(1), 142-159, mar. 2004. (N. da R.) 


\section{Hippocratis Aphorismi*}

\section{I}

Ad extremos morbos, extrema remedia exquisite optima. (Sect. ${ }^{\text {a }}$, Aph. $6^{\circ}$ ).

II

Cum morbis in vigore fuerit, tunc vel tenuissimo victu uti necesse est. (Sect. 1 ${ }^{\mathrm{a}}$, Aph. $8^{\circ}$ ).

III

Lassitudines sponte obortae morbos denunciant. (Sect. $2^{\mathrm{a}}$, Aph. $5^{\circ}$ ).

IV

Si metus et tristitia multo tempore perseverant, melancholicum hoc ipsum. (Sect. $6^{\mathrm{a}}$, Aph. 23).

Deliria cum risu, quidem accidentia securiora: cum studio veró periculosoria. (Sect.

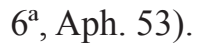

VI

$\mathrm{Ab}$ insania dysenteria, aut hydrops, aut exstasis, bonum. (Sect. $7^{\mathrm{a}}$, Aph. $5^{\circ}$ ).

\section{Luiz Antonio da Silva Peixoto}

Formado na Faculdade de Medicina do Rio de Janeiro em 1837, defendeu nesse ano a tese Considerações gerais sobre a alienação mental, considerada a primeira tese brasileira na área de psiquiatria.

* Em tradução livre, a partir da versão de E. Littré (do grego ao francês):

I. Para doenças extremas, a extrema exatidão do tratamento é o mais eficaz.

II. Quando a doença está em seu auge, então é necessário seguir a dieta mais severa.

III. Lassitudes espontâneas anunciam as doenças.

IV. Quando o medo e a tristeza persistem por muito tempo, é um estado melancólico.

V. Os delírios alegres são menos perigosos que os delírios sérios.

VI. Na loucura, vindo disenteria, ou hidropisia ou transporte (delírio passageiro), bons augúrios. Littré, Emile. Aphorismes d'Hippocrate. Paris: J.B. Baillière, 1844. Recuperado em 18 nov 2013, de: http://archive.org/details/aphorismesdhippo00hipp. (N. da R.) 